\title{
Chemical characterization of dissolved organic matter (DOM) A prerequisite for understanding UV-induced changes of DOM absorption properties and bioavailability
}

\author{
Review Article \\ Author(s): \\ Sulzberger, Barbara; Durisch-Kaiser, Edith \\ Publication date: \\ 2009-06 \\ Permanent link: \\ https://doi.org/10.3929/ethz-b-000016798
}

Rights / license:

In Copyright - Non-Commercial Use Permitted

Originally published in:

Aquatic Sciences 71(2), https://doi.org/10.1007/s00027-008-8082-5 
Aquat. Sci. 71 (2009) 104-126

$1015-1621 / 09 / 020104-23$

Aquatic Sciences

DOI 10.1007/s00027-008-8082-5

(C) Birkhäuser Verlag, Basel, 2009

\author{
Review Article
}

\title{
Chemical characterization of dissolved organic matter (DOM): A prerequisite for understanding UV-induced changes of DOM absorption properties and bioavailability
}

\author{
Barbara Sulzberger ${ }^{1, *}$ and Edith Durisch-Kaiser ${ }^{2}$ \\ ${ }^{1}$ Swiss Federal Institute of Aquatic Science and Technology (Eawag), Überlandstrasse 133, CH-8600 \\ Dübendorf, Switzerland \\ ${ }^{2}$ Institute of Biogeochemistry and Pollution Dynamics, Swiss Federal Institute of Technology Zurich (ETH), \\ Universitätstrasse 16, CH-8092 Zurich, Switzerland
}

Received: 30 November 2007; revised manuscript accepted: 2 December 2008

\begin{abstract}
UV-induced transformations of colored dissolved organic matter (CDOM, which is part of dissolved organic matter, DOM) affect CDOM absorption properties resulting in the loss of color (referred to as photobleaching). CDOM photobleaching increases the penetration depths of the damaging UV-B radiation into water bodies and strongly depends on the wavelength of solar radiation and on the $\mathrm{pH}$ of aquatic systems. UV-induced transformations also affect DOM availability to bacterioplankton, often enhancing the bioavailability of terrigenous DOM and in turn microbial respiration. The combination of UV-induced enhancement of DOM bioavailability and increased export of terrigeneous DOM into estuaries and coastal waters due to climaterelated changes in continental hydrology could result in a UV-mediated positive feedback of $\mathrm{CO}_{2}$ accumulation in the atmosphere.
\end{abstract}

The extent and type of CDOM photobleaching and of UV-induced changes in DOM bioavailability depend on (C)DOM chemical composition, which in turn undergoes drastic changes upon UV-induced transformations. Therefore, the chemical characterization of (C)DOM is key for rationalizing UV-induced transformations. In the second section (after the "Introduction"), we review important methods for the elucidation of the chemical composition of (C)DOM. However, this article is not intended to be comprehensive regarding (C)DOM chemical characterization. An important purpose is to provide photochemical bases for the understanding of UV-induced changes of (C)DOM absorption properties and bioavailability (mainly discussed in the sections "Pathways of DOM phototransformations" and "UV-induced changes of the absorption properties of CDOM").

Key words. DOM characterization; DOM phototransformations; CDOM photobleaching; DOM bioavailability; UV-radiation; climate change.

\section{Introduction}

* Corresponding author phone: +41 443919785 ,

e-mail: sulzberger@eawag.ch

One of the most important substances in aquatic

Published Online First: March 27, 2009 systems that absorbs solar UV radiation is the chromophoric dissolved organic material (CDOM). 
Terrestrial ecosystems are significant sources of CDOM (Bracchini et al., 2006; Duan et al., 2007a; Duan et al., 2007b; Sobek et al., 2007), and rivers serve as important reactors as well as transporters of terrigenous CDOM to lakes, reservoirs, and oceans (Algesten et al., 2004; Blough et al., 1993; Cauwet, 2002; Chen et al., 2004; Conmy et al., 2004; Dittmar et al., 2006; Hansell et al., 2004; Hedges et al., 1997; Hopkinson et al., 1998; Kowalczuk et al., 2003; Kowalczuk et al., 2005; Kowalczuk et al., 2006; Opsahl and Benner, 1997; Opsahl et al., 1999; Waiser and Robarts, 2000; Zanardi-Lamardo et al., 2004). Terrigenous CDOM originates from the decomposition of nonliving plant material, and is introduced into aquatic systems via leaching and runoff from land. CDOM also can be produced through the decay of phytoplankton detritus (Biers et al., 2007; Chen et al., 2004; Kowalczuk et al., 2006; Twardowski and Donaghay, 2001). This source of CDOM has been referred to as "microbially derived" CDOM (McKnight et al., 2001). Furthermore, salt marsh cordgrasses and seagrasses are important sources of CDOM in estuarine and coastal ecosystems (Maie et al., 2005; Stabenau et al., 2004; Wang et al., 2007a).

During riverine transport, and in estuaries and coastal waters, CDOM undergoes photochemical transformations, resulting in the loss of color, mainly in the UV region (referred to as photobleaching) (Blough et al., 1993; Del Vecchio and Blough, 2002; Del Vecchio and Blough, 2004a; Gao and Zepp, 1998; Hefner et al., 2006; Kieber et al., 1990; Minor et al., 2007; Molot et al., 2005; Moran et al., 2000; Rodriguez-Zuniga et al., 2008; Stabenau et al., 2004; Stabenau and Zika, 2004; Twardowski and Donaghay, 2002; Vähätalo and Wetzel, 2004; Vähätalo and Wetzel, 2008; Vodacek et al., 1995; White et al., 2003; Xie et al., 2004). CDOM photobleaching also has been demonstrated in lakes (Brinkmann et al., 2003a; Ma and Green, 2004; Morris and Hargreaves, 1997; Obernosterer and Benner, 2004; Reche et al., 1998; Reche et al., 1999; Reche et al., 2000; Scully et al., 2003). As a consequence of CDOM photobleaching, the UV penetration into water bodies increases and enhances the exposure of aquatic organisms to UV radiation. Aquatic organisms that play important roles in carbon cycling such as phytoplankton, bacterioplankton, and coral reefs are damaged by UV radiation. The biological processes known to be affected by UV-B are primary production (Beardall and Raven, 2004; Leu et al., 2007; Wangberg et al., 2006), bacterioplankton growth (Hernández et al., 2007; Herndl et al., 1993; Jeffrey et al., 1996; Langenheder et al., 2006), and coral bleaching (Anthony et al., 2007; Anthony and Kerswell, 2007), enhancing the warming-related stress on corals (An- thony et al., 2007; Rodriguez-Roman et al., 2006). UV-B damages on algal photosynthesis include inhibitory effects on nutrient uptake and damage to DNA (Beardall and Raven, 2004 and refs. cited therein).

Dissolved organic matter (DOM), which includes $\mathrm{CDOM}$, is a key nutrient and energy source for consumers, including heterotrophic bacteria and metazooplankton (Wetzel, 1992). However, not all chemical forms of DOM are available to these organisms. Photochemical transformations of DOM can increase or decrease DOM bioavailability (Benner and Biddanda, 1998; Bertilsson and Tranvik, 1998; Bertilsson et al., 1999; Biddanda and Cotner, 2003; Brinkmann et al., 2003b; Herndl et al., 1997; Jorgensen et al., 1998; Judd et al., 2007; Kaiser and Herndl, 1997; Kaiser and Sulzberger, 2004; Kieber et al., 1989; Lindell et al., 1995; Mopper et al., 1991; Moran and Zepp, 1997; Obernosterer et al., 1999b; Pullin et al., 2004; Vähätalo et al., 2003; Vähätalo and Wetzel, 2008; Wetzel et al., 1995). The light-induced increase in DOM bioavailability may enhance microbial respiration of DOM with production of $\mathrm{CO}_{2}$ and consumption of $\mathrm{O}_{2}$ (Bertilsson and Tranvik, 1998; Obernosterer and Benner, 2004; Pullin et al., 2004; Vähätalo and Wetzel, 2008) or increase microbial biomass through the microbial loop (Bertilsson et al., 1999; Daniel et al., 2006). Furthermore, mineralization of DOM also occurs as a purely abiotic, lightinduced process (Anesio and Granéli, 2004; Austin and Vivanco, 2006; Bélanger et al., 2006; Benner and Biddanda, 1998; Clark et al., 2004; Gao and Zepp, 1998; Goldstone et al., 2002; Granéli et al., 1996; Granéli et al., 1998; Miller and Zepp, 1995; Minor et al., 2006; Minor et al., 2007; Mopper et al., 1991; Obernosterer and Benner, 2004; Rodriguez-Zuniga et al., 2008; Vähätalo and Wetzel, 2004; Vodacek et al., 1997; Xie et al., 2004).

The photochemical and biological reactivity of DOM depend on its source and hence its chemical composition. Thus understanding the chemical composition of DOM is a prerequisite for rationalizing UV-induced changes of DOM absorption properties and bioavailability. The molecular-level characterization of what has long been referred to as molecularly uncharacterized carbon has largely improved thanks to modern spectroscopic and spectrometric methods, e.g., multidimensional nuclear magnetic resonance (NMR) spectroscopy, and Fourier transform ion cyclotron resonance mass spectrometry (Mopper et al., 2007). In this article, we review selected literature on the chemical characterization of DOM and on how solar UV radiation affects the chemical composition and thus the optical properties and bioavailability of DOM in marine and freshwater systems, focusing on 
dissolved organic carbon (DOC). [Note that in the following text we use "DOM" synonymous to "DOC".] This review article is not intended to be comprehensive regarding DOM chemical characterization; for example, we have not included studies that used stable isotope or electrochemical methods. An important purpose of this article is to provide photochemical basis for the understanding of UV-induced changes of DOM absorption properties and bioavailability. Many studies that we cite in this review article have used artificial or ambient solar radiation and not specifically UV radiation. Since UV (ranging from 280-315 and 315-400 $\mathrm{nm}$ for UV-B and UV-A radiation, respectively) is an important range of the solar spectrum with regard to photochemical processes involving DOM, we refer to these processes in general as UV-induced processes. For convenience we are using the abbreviated notations "UV", "UV-B", and "UV-A" for solar UV, UV-B, and UV-A radiation. The following text is divided into five sections, where each section includes up to four subsections:

(i) Methods for the elucidation of the chemical composition of DOM

(ii) Pathways of DOM phototransformations

(iii) UV-induced changes of the absorption properties of CDOM

(iv) Effects of UV radiation on the bioavailability and mineralization of DOM

(v) Conclusions

\section{Methods for the elucidation of the chemical composition of DOM}

Regarding the utmost complex mixture of chemical compounds contained in DOM, the first question a geochemist asks about DOM pertains to its polydispersity. In the first subsection, we therefore outline methods by which the molecular mass distribution of DOM can be explored.

\section{Molecular mass distribution of DOM}

To obtain the dissolved fraction of natural organic matter, sea- or freshwater samples have to be filtered (e.g., through a $0.45 \mu \mathrm{m}$ filter). Hence "dissolved" organic matter (DOM) is an operational definition. Ultrafiltration then allows the fractionation of DOM into high-molecular-weight (HMW) and low-molecular-weight (LMW) DOM compounds. Ultrafiltration employing a tangential flow ultrafiltration system with a $1 \mathrm{kD}$ nominal weight cutoff membrane was extensively evaluated by Ronald Benner and coworkers (e.g., Benner et al., 1992; Benner et al., 1997) and is widely used for the chemical characterization of DOM. Ultrafiltration may be followed by $\mathrm{C}_{18}$ solid phase extraction (SPE) or XAD chromatography (Brown et al., 2004; Simjouw et al., 2005). It is important to realize that ultrafiltration is based on a physical separation of DOM, whereas SPE and XAD chromatography are based on chemical fractionation, which divide DOM into hydrophilic and hydrophobic compounds.

A widely used method for the elucidation of the molecular mass distribution of DOM at a finer scale, which in addition provides information on the chemical composition of DOM, is size exclusion chromatography (SEC) and high-pressure size exclusion chromatography (HPSEC) (Brinkmann et al., 2003a; Brinkmann et al., 2003b; Brown et al., 2004; Chin et al., 1994; Gaberell et al., 2003; Kaiser and Sulzberger, 2004; Reemtsma and These, 2005; Schmitt et al., 2001; Schwede-Thomas et al., 2005). SEC not only separates DOM compounds based on size (hydrodynamic radii), but also ion-exclusion and hydrophobic interactions of the fractions with the column material can occur (Schmitt et al., 2001). Ideally, both the dissolved organic carbon concentration (DOC) and the absorbance at $254 \mathrm{~nm}$ of the eluents with different retention times are detected (Brinkmann et al., 2003a; Brinkmann et al., 2003b; Kaiser and Sulzberger, 2004; Schmitt et al., 2001) since not all DOM compounds, e.g., polysaccharides, absorb UV light at $254 \mathrm{~nm}$. SEC or HPSEC is sensitive enough to delineate changes in the chemical composition of DOM upon irradiation and/or biodegradation (Brinkmann et al., 2003a; Brinkmann et al., 2003b; Kaiser and Sulzberger, 2004). For example, using SEC Brinkmann and coworkers (2003b) demonstrated that irradiation with simulated solar UV light of humic-derived DOM from an acidic lake resulted in a reduction of the mean hydrodynamic radii of the DOM compounds. Furthermore, new fractions appeared in the SEC which were assigned to aliphatic mono- and dicarboxylic acids such as formic and oxalic acid, which were biologically more labile than the reactants (Fig. 1). Some studies have used SEC or HPSEC followed by mass spectrometry (Reemtsma and These, 2005; Schmitt et al., 2001) or nuclear magnetic resonance (NMR) spectroscopy (Brown et al., 2004) (see also below).

Next to SEC, mass spectrometry is an obvious tool to assess the molecular mass distribution of DOM (Kujawinski et al., 2004; Minor et al., 2007; Reemtsma et al., 2008; Seitzinger et al., 2005; Stabenau et al., 2004; Stabenau and Zika, 2004; Tremblay et al., 2007). For example, Stabenau and Zika (2004) applied a combination of a solid-phase extraction method with electrospray ionization (ESI) continuous flowing ion 


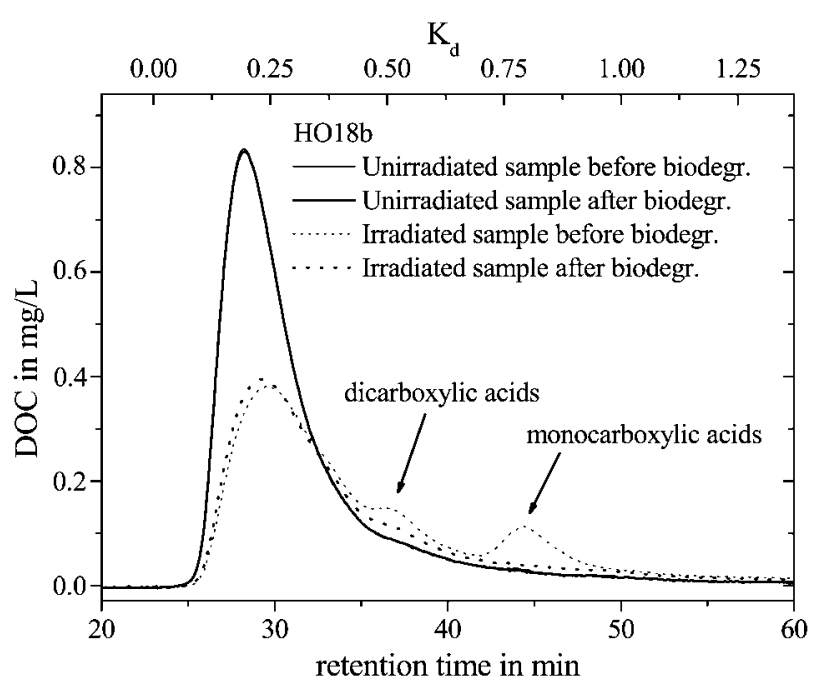

Figure 1. Size exclusion chromatogram of water samples from an acidic lake (Lake Hohloh, Germany; $\mathrm{pH} \sim 4.2$; [DOC] $]_{\text {initial }}=11.0$ $\mathrm{mg} \mathrm{L}^{-1}$ ) before and after irradiation (for $24 \mathrm{~h}$ ) with simulated solar UV radiation, and before and after incubation (for $100 \mathrm{~h}$ ) with natural bacterioplankton (reproduced from Brinkmann et al., $2003 \mathrm{~b}$, with permission from the authors and from the American Chemical Society).

trap mass spectrometry to compare the mass distribution of a seagrass species to that of coastal DOM. They confirmed earlier findings (Hemminga and Duarte, 2000) that seagrasses are a major source of DOM in the coastal ocean.

\section{Bulk characterization of DOM}

The chemical definition of DOM has long relied on elemental analysis $(\mathrm{C}, \mathrm{H}, \mathrm{N}, \mathrm{O}$, and $\mathrm{S})$. The $\mathrm{C} / \mathrm{N}$ ratio serves as an indicator of the source material of DOM present in aquatic systems. The reason for using the $\mathrm{C} / \mathrm{N}$ ratio for the elucidation of the origin of aquatic DOM is that vascular plant tissues are typically carbon-rich $(\mathrm{C} / \mathrm{N}=20-500)$ compared to phytoplankton $(\mathrm{C} / \mathrm{N} \sim 7)$ and bacteria $(\mathrm{C} / \mathrm{N} \sim 4)$, due to the predominance of nitrogen-free bio-macromolecules (e.g. lignin, tannin, hemicellulose, cellulose, cutin, and suberin) over proteins $(\mathrm{C} / \mathrm{N} \sim 3-4)$ (Hedges et al., 1986).

The introduction of gas chromatography and mass spectrometry (GC/MS) in the 1960s allowed scientists to go beyond elemental analysis of DOM. However, compounds need to be volatile to be characterized by GC/MS. The combination of pyrolytic or chemolytic techniques with GC/MS was a major breakthrough in the analysis of DOM. One of the chemolytic reagents used in combination with GC/MS is tetramethyl ammonium hydroxide (TMAH) (Fimmen et al., 2007; Frazier et al., 2005; Hatcher and Clifford, 1994; Wetzel et al., 1995; Zang et al., 2000). Another chemolytic reagent, which was implemented by John
I. Hedges (e.g., Ertel et al., 1984; Ertel et al., 1986; Goni and Hedges, 1992; Hu et al., 1999) and which allows the detection of methoxylated phenols derived from lignin is $\mathrm{CuO}$. The identification and quantification of trace levels of lignin requires the pre-concentration of these compounds, e.g., by SPE (Louchouarn et al., 2000) prior to $\mathrm{CuO}$ oxidation and detection of the oxidation products by GC/MS. Lignin phenols are used as molecular tracers of vascular plant sources and have been measured among the basic $\mathrm{CuO}$ reaction products in various aquatic environments (Duan et al., 2007a; Ertel et al., 1984; Goni and Hedges, 1992; Hernes and Benner, 2003; Opsahl and Benner, 1997; Opsahl and Benner, 1998).

Another separation method that can be combined with MS is high performance capillary electrophoresis (HPCE). This method allows the separation of biomolecules such as amino acids, peptides, proteins, nucleic acids, and DNA and has been used for the chemical characterization of humic substances and marine DOM (Garrison et al., 1995; Hertkorn et al., 2006; Schmitt-Kopplin et al., 1998b; Schmitt-Kopplin and Kettrup, 2003; Vogt et al., 2004).

The drawback of pyrolytic or chemolytic techniques combined with GC/MS is that they are invasive and selective (i.e., certain compounds react more readily than others). Among non-invasive techniques, nuclear magnetic resonance (NMR) spectroscopy, particularly solid-state ${ }^{13} \mathrm{C}$ NMR is frequently used for the identification of the bulk chemical composition of DOM (Baldock et al., 2004; Benner et al., 1992; Brown et al., 2004; Chin et al., 1994; Clair and Sayer, 1997; Cory and McKnight, 2005; Dria et al., 2002; Fan et al., 2000; Fimmen et al., 2007; Gaberell et al., 2003; Hedges et al., 1992; Hertkorn et al., 2006; Kaiser et al., 2003; Kaiser and Sulzberger, 2004; Kulovaara et al., 1996; Maie et al., 2005; McKnight et al., 2003; Mladenov et al., 2007; Novotny et al., 2007; Rodriguez-Zuniga et al., 2008; Schwede-Thomas et al., 2005; Wetzel et al., 1995). ${ }^{13} \mathrm{C}$ NMR spectroscopy enables the determination of the relative abundances of differently bound carbons contained in DOM such as aliphatic carbons, carbohydrate carbons, olefinic and aromatic carbons, carboxylic carbons, amide carbonyl carbons, and carbonyl carbons (aldehydes and ketones). For example, in a seminal study by Benner and coworkers (1992), ${ }^{13} \mathrm{C}$ NMR spectra of HMW DOM indicated that the relative abundance of polysaccharides was high $(\sim 50 \%)$ in surface water of the North Pacific Ocean and decreased to $\sim 25 \%$ in deeper water samples. This technique also allowed a detailed and critical re-evaluation of the widely recognized Redfield-Ketchum-Richards equation (Readfield et al., 1963) in marine phytoplankton (Hedges et al., 2002). Further, ${ }^{13} \mathrm{C}$ NMR spectroscopy 
was used to elucidate the difference in the bulk chemical composition of terrestrial- and algal-derived DOM (Gaberell et al., 2003; Maie et al., 2005; Schwede-Thomas et al., 2005). These studies have shown that algal-derived DOM generally exhibits a lower percentage of aromatic compounds than terrigenous DOM.

NMR techniques require that DOM, usually present at low concentrations in natural water samples, is concentrated using isolation methods such as ultrafiltration, SPE, and XAD chromatography, referred to as HMW DOM, $\mathrm{C}_{18}$ DOM, and XAD DOM, respectively. These methods also allow recovering DOM as a powder that can be directly analyzed by solid-state NMR or redissolved for solution-state NMR. Each of these methods isolates different fractions of DOM, in terms of both chemical composition and molecular weight. $\mathrm{C}_{18} \mathrm{DOM}$ is enriched in aromatic compounds (from lignin and/or aromatic amino acids in proteins), whereas HMW DOM comprises proteins, peptides, polysaccharides, and simple sugars such as aminosugars, 6-deoxy- and methyl sugars (Kaiser et al., 2003; Louchouarn et al., 2000; Quan and Repeta, 2007; Schwede-Thomas et al., 2005; Simjouw et al., 2005).

\section{Molecular-level characterization of DOM}

One-dimensional (1-D) ${ }^{13} \mathrm{C}$ NMR spectroscopy only provides information on the bulk chemical composition of DOM but not on how structures are arranged at the molecular level within DOM. Increasingly, 2-dimensional (2-D) liquid-state multinuclear magnetic resonance techniques are being used (Cook, 2004; Fan et al., 2000; Hertkorn et al., 2006; Kaiser et al., 2003; Kelleher and Simpson, 2006; Lam et al., 2007; Schmitt-Kopplin et al., 1998a; Simpson, 2001; Simpson et al., 2007). The advantage of multidimensional NMR over 1-D methods lies in the much improved spectral resolution and capability of providing information such as ${ }^{1} \mathrm{H}$ covalent network (with Total Correlation Spectroscopy, TOCSY), ${ }^{1} \mathrm{H}^{13} \mathrm{C}^{13}$ or ${ }^{1} \mathrm{H}^{-15} \mathrm{~N}$ linkages (with Heteronuclear Single Quantum Coherence (HSQC) spectroscopy), through-space connectivities (with Nuclear Overhauser Enhanced Spectroscopy, NOESY), and exchange dynamics (exchange spectroscopy) (Cook, 2004). These 2-D NMR parameters greatly facilitate the determination of structures and conformations of extended molecular fragments present in complex macromolecules. Studies using multidimensional NMR spectroscopy revealed that humic substance (HS) in soils is a complex mixture of microbial and plant biopolymers (or stably aggregated components) and their degradation products, but not a distinct chemical category such as oxidized lignin (Kelleher and Simpson, 2006; Simpson et al., 2007; Sutton and Sposito, 2005).

Mass spectrometry (MS) also is used for the molecular-level characterization of DOM, particularly by applying electrospray ionization (ESI), a "soft" technique that ionizes polar compounds from aqueous solution prior to injection into a mass spectrometer (Ashcroft, 1997; Hatcher et al., 2001; Hatcher, 2004; Hertkorn et al., 2006; Kim et al., 2006; Kujawinski et al., 2004; Reemtsma and These, 2005; Reemtsma et al., 2006; Reemtsma et al., 2008; Seitzinger et al., 2005; Stabenau and Zika, 2004; Tremblay et al., 2007; Whitehead and Hedges, 2003). ESI has been combined with various types of mass spectrometry, with ultra-high resolution Fourier transform ion cyclotron resonance mass spectrometry (ESI-FT-ICR-MS) (Hatcher, 2004; Hertkorn et al., 2006; Kim et al., 2006; Kujawinski et al., 2004; Reemtsma et al., 2006; Reemtsma et al., 2008; Sleighter and Hatcher, 2008; Tremblay et al., 2007), tandem mass spectrometry (ESI-MS/MS) (Whitehead and Hedges, 2003), quadrupole time-of-flight mass spectrometry (ESI-QTOF-MS) (Reemtsma and These, 2005), and continuous flowing ion trap mass spectrometry (ESI-cf-MS) (Stabenau and Zika, 2004). The combination of ESI with other ionization techniques, such as chemical ionization and photoionization, would allow an overly improved analysis of DOM compounds (SchmittKopplin, pers. comm.). The advantage of mass spectrometry over NMR spectroscopy is that also LMW DOM compounds at ambient natural concentrations can be identified (Reemtsma and These, 2005; Seitzinger et al., 2005; Stabenau and Zika, 2004; Whitehead and Hedges, 2003).

Several studies have used a combination of separation, spectrometric, and spectroscopic methods for the molecular-level characterization of DOM and the elucidation of its three-dimensional structure (Fan et al., 2000; Fimmen et al., 2007; Hertkorn et al., 2006; Paul et al., 2006; Rodriguez-Zuniga et al., 2008; Schmitt-Kopplin et al., 1998a; Schulten and Schnitzer, 1997; Simjouw et al., 2005). For example, Fan and coworkers (2000) combined one- and two-dimensional NMR spectroscopy, Fourier transform infrared (FTIR) spectroscopy, and pyrolysis GC/MS to chemically characterize forest soil humic substance. They identified the amino acids Gly, Ala, Leu, Ile, Val, Asp, Ser, $\mathrm{Thr}$, Clu, and Pro as peptidic, and analysis with ${ }^{1} \mathrm{H}$ NOESY, TOCSY, and HSQC indicated that the peptidic side chains were mobile, whereas aromatic groups were relatively rigid. Based on a combination of separation, spectrometric and spectroscopic methods with molecular mechanics calculations, Schulten and Schnitzer (1997) proposed a three-dimensional structure of soil humic acid including 738 atoms $\left(\mathrm{C}_{308} \mathrm{H}_{335} \mathrm{O}_{90}\right.$ 
$\mathrm{N}_{5}$ ). In a similar fashion, the combination of ultrafiltration, NMR spectroscopy, capillary electrophoresis, and FT-IRC-MS allowed the identification of refractory carboxylic-rich acyclic molecules (CRAM), a component of marine DOM that until recently was recognized to belong to the "molecularly uncharacterized" component of DOM that derives from highly decomposed biomolecules (Hertkorn et al., 2006).

\section{Elucidation of the origin and chemical composition of CDOM with absorption and fluorescence spectroscopy}

Since the optical properties and the chemical composition of CDOM are interrelated, absorption and fluorescent spectroscopy can be used in addition to the methods mentioned in the previous subsections to elucidate the chemical composition of CDOM (for a recent review on the chemistry of ocean color see Coble, 2007). The specific UV-absorbance of CDOM (SUVA), which is defined as the UV absorbance of a water sample at a given wavelength in the UV region (usually at $280 \mathrm{~nm}$ ), normalized to DOC concentration, has been shown to correlate with the fraction of aromatic compounds contained in CDOM (Chin et al., 1994; Gaberell et al., 2003; Hassellöv, 2005; Mladenov et al., 2007; Weishaar et al., 2003).

In addition to UV/VIS absorption spectroscopy, fluorescence spectroscopy has been used to delineate the chemical composition and origin of CDOM, particularly three-dimensional excitation-emission matrix (EEM) fluorescence spectroscopy (Boehme et al., 2004; Boyd and Osburn, 2004; Coble et al., 1990; Conmy et al., 2004; Cory and McKnight, 2005; Fulton et al., 2004; Jiang et al., 2008; Kowalczuk et al., 2003; Kowalczuk et al., 2005; McKnight et al., 2001; Mladenov et al., 2007; Murphy et al., 2008; Stedmon and Markager, 2005a; Stedmon and Markager, 2005b; Vähätalo and Wetzel, 2008; Zepp et al., 2004). The combination of EEM with parallel factor data analysis allows the chemical identification of fluorophores, e.g., quinone-like fluorophores (Cory and McKnight, 2005; Mladenov et al., 2007; Stedmon and Markager, 2005a; Stedmon and Markager, 2005b). EEM also provides information on the redox properties of DOM (Cory and McKnight, 2005).

The fluorescence index (FI), which is the ratio of emission intensity $(450 \mathrm{~nm} / 500 \mathrm{~nm})$ at $370 \mathrm{~nm}$ excitation (McKnight et al., 2001), is correlated to the relative contribution of autochthonous versus terrigenous DOM, and therefore a valuable tool for DOM source identification (Battin, 1998; Boyd and Osburn, 2004; Cory and McKnight, 2005; Fimmen et al., 2007; McKnight et al., 2001; Mladenov et al., 2007; Schwede-Thomas et al., 2005). For example, McKnight and coworkers (2001) found a value of $\sim 1.9$ for microbial-derived fulvic acid and a value of $\sim 1.4$ for terrestrial-derived fulvic acid.

\section{Pathways of DOM phototransformations}

There exist several pathways of UV-induced DOM transformations, depending on DOM chemical composition and on environmental factors such as the presence of iron (Fig. 2). The following subsections describe these pathways and discuss how the chemical composition and origin of DOM affect its photoreactivity.

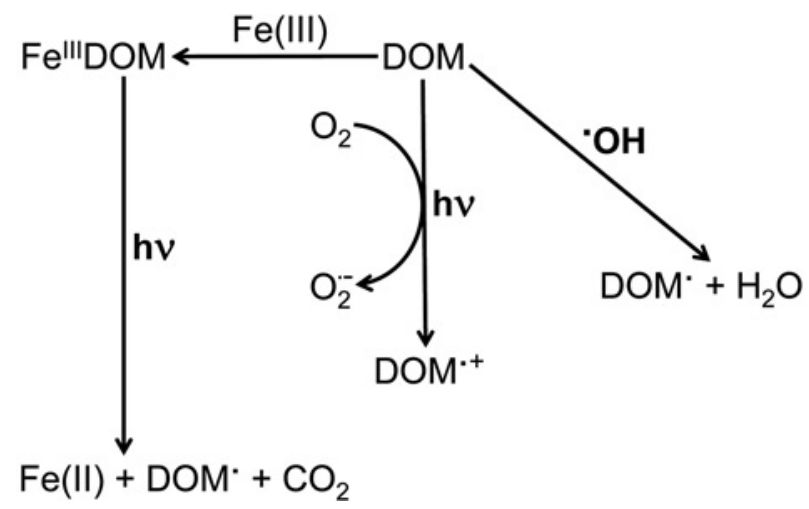

Figure 2. Pathways of light-induced transformations of DOM; from left to right: (i) via photolysis of Fe(III)-DOM complexes, (ii) via direct photochemical transformations of DOM, and (iii) via OH attack of DOM.

\section{Direct photochemical transformations of CDOM}

The fraction of DOM that absorbs solar radiation reaching the earth surface ( $65 \%$, Blough et al., 1993) is referred to as CDOM (see also above). During direct photochemical transformations, CDOM itself acts as the primary chromophore. The deactivation of an electronically excited state of CDOM then occurs via, e.g., ionization of CDOM to produce hydrated electrons $\left(\mathrm{e}_{\mathrm{aq}}^{-}\right)$(Blough and Zepp, 1995 and refs. cited therein; Bruccoleri et al., 1993; Wang et al., 2007b; Zepp et al., 1987):

$\mathrm{CDOM}+\mathrm{h} v \rightarrow \mathrm{CDOM}^{++}+\mathrm{e}_{\mathrm{aq}}^{-}$

These hydrated electrons further react in various ways, e.g., with molecular oxygen (which is a triplet state in its ground state) yielding superoxide $\left(\mathrm{O}_{2}^{--}\right)$ (Blough and Zepp, 1995 and refs. cited therein; Bruccoleri et al., 1993):

$\mathrm{e}_{\mathrm{aq}}^{-}+{ }^{3} \mathrm{O}_{2} \rightarrow \mathrm{O}_{2}^{--}$

The organic radical, which may be relatively longlived (Paul et al., 2006), can add molecular oxygen to form a peroxy radical cation (Bruccoleri et al., 1993), 
$\mathrm{CDOM}^{\cdot+}+{ }^{3} \mathrm{O}_{2} \rightarrow \mathrm{CDOMO}_{2}^{\cdot+}$

which undergoes further reactions yielding the final CDOM oxidation product(s). Upon irradiation of CDOM the content of aromatic carbons generally decreases (Kujawinski et al., 2004; Kulovaara et al., 1996; Minor et al., 2007; Opsahl and Benner, 1998; Schmitt-Kopplin et al., 1998a; Scully et al., 2004), so that compounds with low double bond equivalent and high oxygen content remain after phototransformations (Kujawinski et al., 2004).

In oligotrophic water bodies, in which CDOM is the main light-absorbing component, the rate of photochemical CDOM transformation, $\mathrm{R}_{\mathrm{p}}$, can be approximated as,

$\mathrm{R}_{\mathrm{p}} \approx 2.303 \times \int_{\lambda} \mathrm{W}(\lambda) \mathrm{a}(\lambda) \mathrm{D}(\lambda) \Phi_{\mathrm{p}}(\lambda) \mathrm{d} \lambda$

where $\mathrm{W}(\lambda)$ is the spectral photon flux that hits the surface of a water body (in einstein $\mathrm{m}^{-2} \mathrm{~s}^{-1} \mathrm{~nm}^{-1}$ or millieinstein $\mathrm{cm}^{-2} \mathrm{~s}^{-1} \mathrm{~nm}^{-1}$ ) (also called incident light intensity), $\mathrm{a}(\lambda)$ is the decadic absorption coefficient in $\mathrm{m}^{-1}$ or $\mathrm{cm}^{-1}$ (absorbance of the water body divided by the optical pathlength), $\mathrm{D}(\lambda)$ is related to the angle of refraction, $\mathrm{D}(\lambda)=\left(\cos \phi_{\lambda}\right)^{-1}$, and $\Phi_{\mathrm{p}}(\lambda)$ is the quantum yield of primary photoproduct formation (see Eq. 1). According to the rate expression given by Eq. 4, the rate of direct photochemical CDOM transformation is linearly dependent on the decadic absorption coefficient $\mathrm{a}(\lambda)$, which in turn depends on the concentration and the absorption properties of CDOM.

The absorption properties and thus the reactivity of CDOM toward direct photochemical transformations depend on the chemical composition of CDOM and thus on its origin. A number of studies have shown that terrigenous CDOM exhibits a higher photoreactivity than algal-derived CDOM (Bertilsson and Jones, 2003; Biddanda and Cotner, 2003; Chen et al., 2004; Clair and Sayer, 1997; Gaberell et al., 2003; Meunier et al., 2005; Minor et al., 2007; Obernosterer and Benner, 2004; Opsahl and Benner, 1998; Scully et al., 2004; Vähätalo and Wetzel, 2004). This phenomenon can be rationalized in terms of the higher percentage of aromatic compounds in allochthonous CDOM as compared to autochthonous CDOM (Chin et al., 1994; Clair and Sayer, 1997; Dittmar et al., 2006; Gaberell et al., 2003; Maie et al., 2005; McKnight et al., 1991; Minor et al., 2007; Reemtsma and These, 2005; Schwede-Thomas et al., 2005; Stubbins et al., 2008). The absorption properties also depend on the molecular weight of CDOM (Blough and Green, 1995; Chin et al., 1994; Del Vecchio and Blough, 2004b; Stabenau et al., 2004; Stabenau and Zika, 2004). For example, the molar absorptivity of aquatic humic substances at $280 \mathrm{~nm}, \varepsilon_{280} \mathrm{~nm}$ (in L (mole DOC $)^{-1} \mathrm{~cm}^{-1}$ ), has been demonstrated to be linearly correlated with their molecular weight (Chin et al., 1994). Regarding the chemical origin of light absorption by CDOM, Del Vecchio and Blough (2004b) hypothesized that the long wavelength absorption tail of humic substances $(>350 \mathrm{~nm})$ arises from coupled intramolecular charge-transfer transitions between hydroxy-aromatic donors and quinoid acceptors formed by the partial oxidation of lignin precursors. This model is in line with the observation that (poly)phenolic structures within CDOM are particularly sensitive to phototransformations (Judd et al., 2007; Opsahl and Benner, 1998; Schmitt-Kopplin et al., 1998a; Scully et al., 2004).

The rate of direct photochemical CDOM transformations also depends on the reaction quantum yield, $\Phi_{\mathrm{p}}(\lambda)$ (Eq. 4). To assess quantum yields of primary photoproduct formation and to elucidate the mechanisms involved in light absorption and in the deactivation of excited states of CDOM, time-resolved spectroscopic methods are required, which so far have been applied in only a few environmental photochemical studies (Bruccoleri et al., 1993; Del Vecchio and Blough, 2004b; Wang et al., 2007b). Many studies have, however, determined apparent quantum yields of photochemical decomposition of CDOM (Vähätalo and Wetzel, 2004) and stable photoproduct formation like dissolved inorganic carbon (DIC) (Gao and Zepp, 1998; Johannessen and Miller, 2001; Miller and Zepp, 1995), CO (Bélanger et al., 2006; Gao and Zepp, 1998; Stubbins et al., 2008; Valentine and Zepp, 1993; Zhang et al., 2006; Ziolkowski and Miller, 2007), and carbonyl compounds (Kieber et al., 1990). Regarding stable photoproduct formation, one has to bear in mind that these can be formed via direct and indirect photochemical transformations of CDOM, e.g., attack of CDOM by reactive intermediates that are produced in primary photochemical processes (Del Vecchio and Blough, 2002) or via iron-catalyzed CDOM transformation (Gao and Zepp, 1998).

\section{Indirect photochemical transformations of DOM via OH attack}

If DOM is not colored, i.e., if it does not absorb solar radiation that reaches the Earth surface, it may be transformed via indirect photochemical reactions (also referred to as photosensitized reactions). One important pathway is reaction of DOM with the hydroxyl radical ('OH) (Anesio and Granéli, 2004; Brinkmann et al., 2003a; Brinkmann et al., 2003b; Gao and Zepp, 1998; Molot et al., 2005; Pullin et al., 2004; Schmitt-Kopplin et al., 1998b; Scully et al., 2003; White et al., 2003; Xie et al., 2004), e.g., 
abstraction of a hydrogen atom from DOM by ${ }^{\circ} \mathrm{OH}$ (Blough and Zepp, 1995 and refs. cited therein):

$\mathrm{DOM}+{ }^{\cdot} \mathrm{OH} \rightarrow \mathrm{DOM}^{\cdot}+\mathrm{H}_{2} \mathrm{O}$

Oxygen addition then leads to an organic peroxyl radical, which may eliminate $\mathrm{HO}_{2}^{*}$ :

$\mathrm{DOM}^{\bullet}+\mathrm{O}_{2} \rightarrow \mathrm{DOMOO}^{\circ} \rightarrow \mathrm{DOM}_{\mathrm{ox}}+\mathrm{HO}_{2}^{*}$

Another reaction pathway is addition of ${ }^{\circ} \mathrm{OH}$ to $\mathrm{DOM}$, followed by oxygen addition and elimination of $\mathrm{HO}_{2}$. For example, the addition of ${ }^{\circ} \mathrm{OH}$ to benzene in the presence of oxygen results in phenol and $\mathrm{HO}_{2}^{*}$ (Warneck and Wurzinger, 1988):

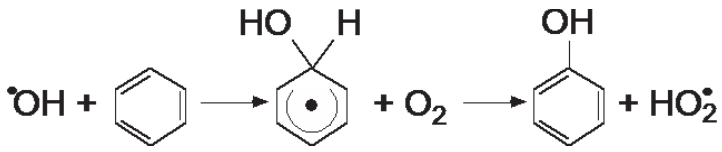

In sunlit aquatic systems, there are several pathways of $\mathrm{OH}$ formation (Blough and Zepp, 1995; Vaughan and Blough, 1998 and refs. cited in these articles): (i) photolysis of $\mathrm{NO}_{3}^{-}$, (ii) $\mathrm{H}$-abstraction from water by ${ }^{3} \mathrm{CDOM}^{*}$, and (iii) photo-Fenton reactions (Fig. 3), the latter being an important pathway in ironrich aquatic systems (Anesio and Granéli, 2004; Brinkmann et al., 2003a; Brinkmann et al., 2003b; Gao and Zepp, 1998; Molot et al., 2005; Southworth and Voelker, 2003; White et al., 2003; Xie et al., 2004). White and coworkers (2003) attributed the high rate of photochemical ${ }^{\circ} \mathrm{OH}$ formation in the acidic Satilla River water $\left(0.4 \mathrm{nM} \mathrm{s}^{-1}\right)$ mainly to the involvement of photo-Fenton reactions. Molot and coworkers (2005) found that the oxidative loss of stream DOM by reaction with photo-produced ${ }^{\circ} \mathrm{OH}$ was highest at $\mathrm{pH} 4$ but still significant at $\mathrm{pH}$ 7. The strong $\mathrm{pH}$-dependence of photooxidation of $\mathrm{DOM}$ by ${ }^{\circ} \mathrm{OH}$ can be interpreted in terms of the $\mathrm{pH}$-dependence of the various reactions involved in photo-Fenton systems (Anesio and Graneli, 2004; Balmer and Sulzberger, 1999; Molot et al., 2005).

Several studies have assessed the relative importance of DOM transformations via reaction with ${ }^{\circ} \mathrm{OH}$, as compared to other photochemical transformation processes of DOM (Goldstone et al., 2002; Hefner et al., 2006; Minor et al., 2007; Molot et al., 2005; Pullin et al., 2004). Some studies found that reactions with 'OH play a minor role in photobleaching and abiotic mineralization of humic and fulvic substances (Goldstone et al., 2002; Hefner et al., 2006; Minor et al., 2007). On the other hand, Pullin and coworkers (2004) reported that treatment of river water samples with $\cdot \mathrm{OH}$ (produced by gamma radiation) had a larger

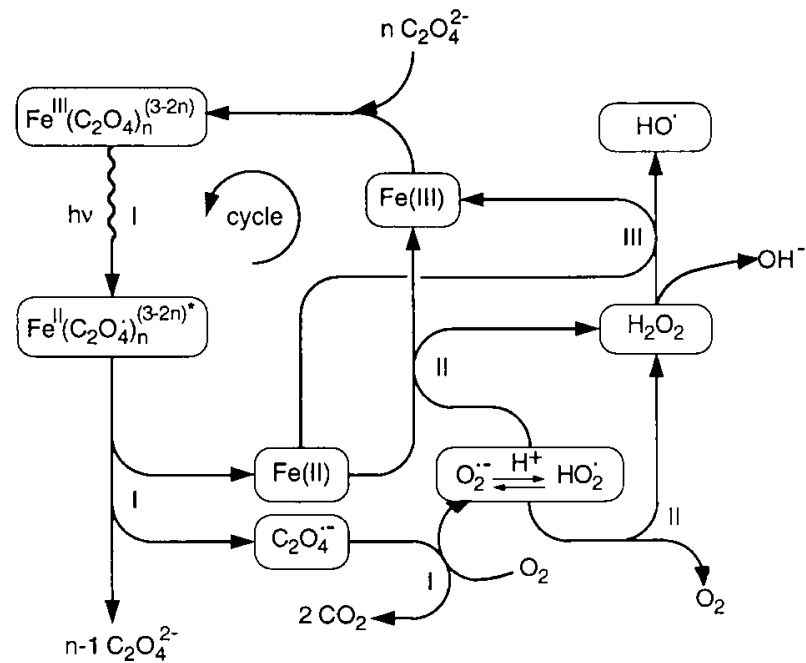

Figure 3. Scheme of hydroxyl radical ( $\mathrm{\circ} \mathrm{OH})$ formation in photoFenton systems. For simplicity the reactions are depicted with oxalate as a model compound for DOM (modified from Zuo and Holgné, 1992).

effect on the production of LMW organic acids (acetic, formic, malonic, and oxalic acid) than irradiation of the water samples with ambient sunlight.

\section{Photochemical transformations of DOM via photolysis of Fe(III)-DOM complexes}

In iron-rich surface waters, an important pathway of photochemical DOM transformation is photolysis of Fe(III)-DOM complexes (Anesio and Granéli, 2004; Brinkmann et al., 2003a; Brinkmann et al., 2003b; Gao and Zepp, 1998; Kaiser and Sulzberger, 2004; Meunier et al., 2005; Molot et al., 2005; White et al., 2003; Xie et al., 2004). Photolysis of Fe(III)-DOM complexes is likely to occur in a similar way as photolysis of $\mathrm{Fe}(\mathrm{III})$-oxalate or -citrate complexes (Fig. 3) (Balmer and Sulzberger, 1999; Borer et al., 2007; Faust and Zepp, 1993; Waite and Morel, 1984; Zuo and Holgné, 1992), i.e., to involve carboxyl groups contained in DOM as Fe(III) ligands (Meunier et al., 2005; Sulzberger and Laubscher, 1995; Voelker et al., 1997). Photolysis of such complexes can be described by the following reaction sequence: Ligandto-metal charge-transfer transition creating a chargetransfer state,

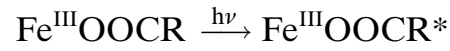

which is, in part, thermally deactivated,

$\mathrm{Fe}^{\mathrm{III}} \mathrm{OOCR}^{*} \stackrel{\text { th }}{\longrightarrow} \mathrm{Fe}^{\mathrm{III}} \mathrm{OOCR}$

and, in part, forms $\mathrm{Fe}(\mathrm{II})$ and the radical $\mathrm{RCOO}^{*}$ :

$\mathrm{Fe}^{\mathrm{III}} \mathrm{OOCR}^{*} \rightarrow \mathrm{Fe}(\mathrm{II})+\mathrm{RCOO} *$ 
It is likely that the radical RCOO' undergoes decarboxylation like simple carboxylic acids such as oxalate or citrate, particularly with DOM compounds that exhibit hydroxyl groups in $\alpha$-position to carboxylic acid groups (Abrahamson et al., 1994; Borer et al., 2007):

$\mathrm{RCOO}^{\bullet} \rightarrow \mathrm{R}^{\bullet}+\mathrm{CO}_{2}$

Carbon-centered radicals $\mathrm{R}^{\cdot}$ may react with each other to form non-radical products. If the radical $\mathrm{R}^{*}$ is an alkyl radical, then formation of organic peroxyl radicals by addition of $\mathrm{O}_{2}$ is likely to take place (Blough and Zepp, 1995 and refs. cited therein). Peroxyl radicals can further react by different pathways (Blough and Zepp, 1995 and refs. cited therein): (i) termination reactions to form non-radical and nonperoxidic products, e.g., polymerization products, (ii) abstraction of $\mathrm{HO}_{2}^{-}$, and (iii) $\mathrm{H}$-atom abstraction to generate organic peroxides and secondary radicals. The study by Voelker and coworkers (1997) with heterogeneous iron systems and Suwannee River Fulvic Acid (SRFA) suggests that photolysis of Fe(III)-SRFA complexes and subsequent reactions are not dominant sources of $\mathrm{HO}_{2}^{\circ}$.

Several studies suggest that LMW compounds are more reactive towards $\mathrm{UV}$-induced $\mathrm{Fe}$ (II) formation than HMW compounds, both in sea- and freshwater samples (Meunier et al., 2005; Powell and WilsonFinelli, 2003; Song et al., 2005). This higher reactivity of LMW materials in UV-induced reduction of Fe(III) may be rationalized by more efficient photolysis of $\mathrm{Fe}$ (III) complexes with LMW ligands, as compared to HMW ligands, possibly due to a higher content of carboxyl functional groups contained in aquatic LMW DOM (Reemtsma and These, 2005). Indeed, (poly)carboxylic acids with a limited number of hydroxy groups have been identified as the major compound class in fulvic acid isolates (Reemtsma et al., 2006). Based on a combination of experimental studies and mathematical kinetic modeling, Meunier and coworkers (2005) hypothesized that in irradiated LMW DOM fractions from a lake, Fe(II) was formed through photolysis of $\mathrm{Fe}(\mathrm{III})-\mathrm{DOM}$ complexes. Kinetic modeling further suggested that $\mathrm{Fe}(\mathrm{II})$ was stabilized by a ligand that likely was formed during irradiation (Fig. 4, Table 1).

In iron-rich, sunlit aquatic systems, the three pathways of DOM phototransformations discussed in this section may take place simultaneously, and the iron-catalyzed pathways are coupled. Furthermore, photooxidation of DOM also may take place at the surface of Fe(III)-(hydr)oxides (Voelker et al., 1997; Waite and Morel, 1984; Wells et al., 1991). It is not trivial to distinguish between the various types of ironcatalyzed phototransformations of DOM. One ap-

Table 1. Reactions and kinetic parameters used in the kinetic model (modified from Meunier et al., 2005).

\begin{tabular}{|c|c|c|c|}
\hline No. & Equation & $\begin{array}{l}\text { Kinetic parameters for the } \\
\text { LMW DOM sample } \\
\text { from Lake Murten }\end{array}$ & References \\
\hline $1^{\mathrm{a}}$ & $\mathrm{Fe}(\mathrm{III})+\mathrm{h} v \rightarrow \mathrm{Fe}(\mathrm{II})+$ products & $\mathrm{k}=0.001 \mathrm{~s}^{-1}$ & Miller et al. $(1995)^{\mathrm{b}}$ \\
\hline $\begin{array}{l}2^{c} \\
3\end{array}$ & $\begin{array}{l}\mathrm{CDOM} \stackrel{\mathrm{O}_{2}, \mathrm{~h} v}{\longrightarrow} \mathrm{CDOM}^{++}+\mathrm{O}_{2}^{--} \\
\mathrm{Fe}(\mathrm{III})+\mathrm{O}_{2}^{--} \rightarrow \mathrm{Fe}(\mathrm{II})+\mathrm{O}_{2}\end{array}$ & $\begin{array}{l}\mathrm{r}=9.9 \times 10^{-8} \mathrm{M} \mathrm{s}^{-1}(\mathrm{fp} 1) \\
\mathrm{k}=<10^{3} \mathrm{M}^{-1} \mathrm{~s}^{-1}(\mathrm{fp} 2)\end{array}$ & \\
\hline $\begin{array}{r}4 \\
5 \\
6 \\
7 \\
8 \\
9 \\
10\end{array}$ & $\begin{array}{l}\mathrm{Fe}(\mathrm{II})+\mathrm{O}_{2} \rightarrow \mathrm{Fe}(\mathrm{III})+\mathrm{O}_{2}^{--} \\
\mathrm{Fe}{ }^{\mathrm{II}} \mathrm{L}+\mathrm{O}_{2} \rightarrow \mathrm{Fe}^{\mathrm{III}} \mathrm{L}+\mathrm{O}_{2}^{--} \\
\mathrm{Fe}(\mathrm{II})+\mathrm{O}_{2}^{\cdot-}+2 \mathrm{H}^{+} \rightarrow \mathrm{Fe}(\mathrm{III})+\mathrm{H}_{2} \mathrm{O}_{2} \\
\mathrm{Fe}^{\mathrm{II}} \mathrm{L}+\mathrm{O}_{2}^{\cdot-}+2 \mathrm{H}^{+} \rightarrow \mathrm{Fe}^{\mathrm{III}} \mathrm{L}+\mathrm{H}_{2} \mathrm{O}_{2} \\
\mathrm{Fe}(\mathrm{II})+\mathrm{H}_{2} \mathrm{O}_{2} \rightarrow \mathrm{Fe}(\mathrm{III})+{ }^{\cdot} \mathrm{OH}+\mathrm{OH}^{-} \\
\mathrm{Fe}^{\mathrm{II}} \mathrm{L}+\mathrm{H}_{2} \mathrm{O}_{2} \rightarrow \mathrm{Fe}^{\mathrm{III}} \mathrm{L}+{ }^{\circ} \mathrm{OH}+\mathrm{OH}^{-} \\
\mathrm{Fe}^{\mathrm{III}} \mathrm{L} \rightarrow \mathrm{Fe}(\mathrm{III})+\mathrm{L}\end{array}$ & $\begin{array}{l}\mathrm{k}=20.78 \mathrm{M}^{-1} \mathrm{~s}^{-1} \\
\mathrm{k}=0.21 \mathrm{M}^{-1} \mathrm{~s}^{-1}(\mathrm{fp} 3) \\
\mathrm{k}=1.00 \times 10^{7} \mathrm{M}^{-1} \mathrm{~s}^{-1} \\
\mathrm{k}=5.6 \times 10^{4} \mathrm{M}^{-1} \mathrm{~s}^{-1}(\mathrm{fp} 4) \\
\mathrm{k}=7.86 \times 10^{4} \mathrm{M}^{-1} \mathrm{~s}^{-1} \\
\mathrm{k}=<10^{2} \mathrm{M}^{-1} \mathrm{~s}^{-1}(\mathrm{fp} 5) \\
\mathrm{k}=1.00 \times 10^{10} \mathrm{M}^{-1} \mathrm{~s}^{-1}\end{array}$ & $\begin{array}{l}\text { King }(1998)^{\mathrm{d}} \\
\text { Rush and Bielski }(1985)^{\mathrm{e}} \\
\text { King and Farlow }(2000)^{\mathrm{f}}\end{array}$ \\
\hline $\begin{array}{l}11 \\
12 \\
13\end{array}$ & $\begin{array}{l}\mathrm{O}_{2}^{--}+\mathrm{O}_{2}^{--}+2 \mathrm{H}^{+} \rightarrow \mathrm{H}_{2} \mathrm{O}_{2}+\mathrm{O}_{2} \\
\mathrm{O}_{2}^{--}+\text {sinks } \rightarrow \text { products } \\
\mathrm{Fe}^{2+}+\mathrm{L} \leftrightarrow \mathrm{Fe}^{\mathrm{II}} \mathrm{L}\end{array}$ & $\begin{array}{l}\mathrm{k}=3.98 \times 10^{4} \mathrm{M}^{-1} \mathrm{~s}^{-1} \\
\mathrm{k}=4.63 \mathrm{~s}^{-1} \\
\mathrm{~K}=>10^{10} \mathrm{M}^{-1}(\mathrm{fp} 6)\end{array}$ & $\begin{array}{l}\text { Zafiriou }(1990)^{\mathrm{g}} \\
\text { Estimated from Voelker et al. }(2000) \text {, } \\
\text { and Goldstone and Voelker }(2000)^{\mathrm{h}}\end{array}$ \\
\hline
\end{tabular}

$\mathrm{fp}=$ fitting parameter.

${ }^{a} \mathrm{Fe}$ (III) stands for total dissolved Fe(III) in the LMW DOM sample, whose initial concentration was $6.8 \mathrm{nM}$.

${ }^{\mathrm{b}}$ We assumed rate constants of photolysis of Fe(III) complexes in the range of that suggested by Miller et al. (1995).

${ }^{c}[\mathrm{CDOM}]=52 \mu \mathrm{M}$ in the LMW DOM sample based on measured DOC concentration and assuming that $\sim 65 \%$ of DOC is colored. The rate, $r$, of superoxide formation includes the CDOM concentration, $r=k x[C D O M]$.

${ }^{\mathrm{d}}$ Rate constant given by King (1998) for $\mathrm{I}=0$, corrected for $\mathrm{I}=7 \mathrm{mM}$ using Debye Hückel; alkalinity $=3.4 \mathrm{mM}, \mathrm{pH}=8.2$.

${ }^{\mathrm{e}}$ For inorganic, dissolved $\mathrm{Fe}(\mathrm{II})$ at $\mathrm{pH}>6$.

${ }^{\mathrm{f}}$ Rate constant given by King and Farlow (2000) for $\mathrm{I}=0$, corrected for $\mathrm{I}=7 \mathrm{mM}$ using Debye Hückel; alkalinity $=3.4 \mathrm{mM}$, $\mathrm{pH}=8.2$.

${ }^{\mathrm{g}}$ This rate constant was calculated according to Zafiriou (1990) as follows: $\operatorname{logk}=12.7-1.0(\mathrm{pH})$, with $\mathrm{pH}=8.2$.

${ }^{\mathrm{h}}$ This rate constant for reaction of superoxide with additional sinks is a rough estimate based on Table 1 in Voelker et al. (2000) and Figure 2 in Goldstone and Voelker (2000). 


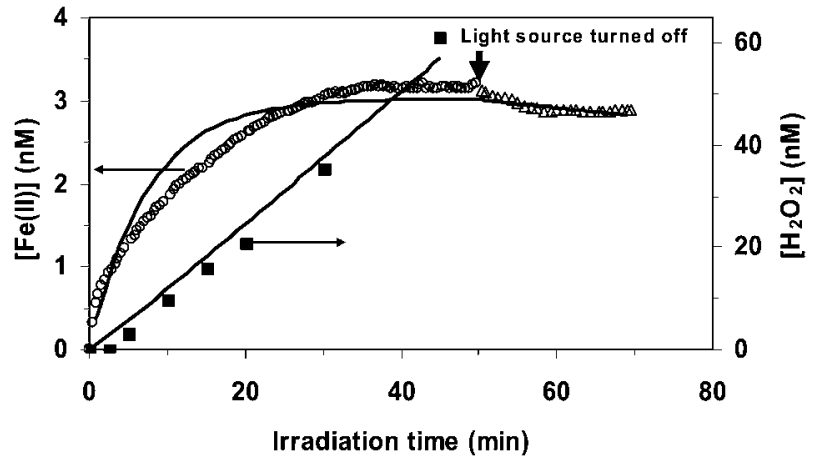

Figure 4. Experimental data (symbols) and modeling results (solid lines) of the concentrations of $\mathrm{Fe}(\mathrm{II})$ and $\mathrm{H}_{2} \mathrm{O}_{2}$ during and after irradiation with simulated sunlight $\left(\mathrm{I}_{0} \sim 1.0 \mathrm{~kW} \mathrm{~m}{ }^{-2}\right)$ of LMW $\operatorname{DOM}(\mathrm{pH}=8.2)$ from Lake Murten (Switzerland) (from Meunier et al., 2005; copyright Eawag, Dübendorf, 2005; reproduced with permission from Eawag).

proach that allows this distinction is the combination of laboratory experiments with mathematical kinetic modeling (Meunier et al., 2005; Voelker et al., 1997) (Fig. 5). Another approach is the comparison of the loss of carboxyl groups and formation of $\mathrm{CO}_{2}$ (Xie et al., 2004).

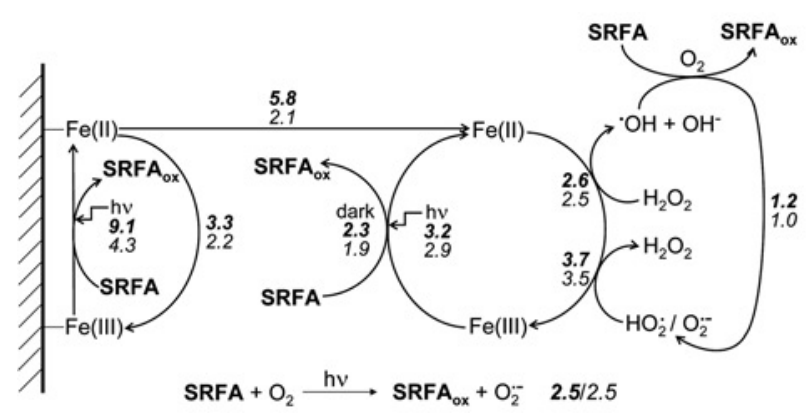

Figure 5. Pathways of light-induced transformations of Suwannee River Fulvic Acid (SRFA) in irradiated, aerated systems, containing initially $40 \mu \mathrm{M}$ Fe in the form of lepidocrocite $(\gamma-\mathrm{FeOOH})$ and $10 \mathrm{mg} \mathrm{L}^{-1}$ SRFA. The numbers in italics indicate the amount of iron (in $\mu \mathrm{M}$ ) oxidized or reduced by each of the depicted process after 300 min of irradiation at $\mathrm{pH} 3$ (top numbers) and at $\mathrm{pH} 5$ (bottom numbers). These numbers were assessed with the help of a mathematical kinetic model using information gained from separate experiments in simpler systems. The rate of light-induced oxidation of SRFA at the surface of $\gamma$-FeOOH was highest in this system, followed by photolysis of Fe(III)-SRFA complexes in solution, followed by photolysis of SRFA itself, followed by thermal oxidation of SRFA by $\mathrm{Fe}$ (III), and finally by the oxidation of SRFA via ${ }^{\circ} \mathrm{OH}$ attack, where the hydroxyl radicals were formed in the Fenton reaction (modified from Voelker et al., 1997).

\section{UV-induced changes of the absorption properties of CDOM}

As stated in the Introduction, photochemical transformations of CDOM often result in the loss of color in terms of a decrease in the absorption coefficient $\mathrm{a}(\lambda)$ (referred to as photobleaching of $\mathrm{CDOM}$ ).
Hence photobleaching is the result of CDOM photodegradation and is often accompanied by a decrease in the molecular weight of CDOM (Brinkmann et al., 2003a; Frimmel, 1998; Stabenau et al., 2004; Stabenau and Zika, 2004; Tremblay et al., 2007). The rate of CDOM photobleaching has been shown to depend on various factors including (i) intensity and wavelength of solar radiation (Del Vecchio and Blough, 2002; Gao and Zepp, 1998; Molot and Dillon, 1997b), (ii) salinity and the presence of iron (Gao and Zepp, 1998; Hefner et al., 2006; Minor et al., 2006; Molot and Dillon, 1997b), (iv) water residence time (Chen et al., 2007; Larson et al., 2007), (v) the extent of stratification (Chen et al., 2007; Del Vecchio and Blough, 2002; Del Vecchio and Blough, 2004a; Vodacek et al., 1997), and (vi) pH (Brinkmann et al., 2003a; Molot and Dillon, 1997b; Molot et al., 2005). As a consequence of CDOM photobleaching, the penetration of UV radiation into water bodies increases and enhances the exposure of aquatic organisms, e.g., phytoplankton, to the damaging UV-B radiation.

Photobleaching of CDOM can occur through the various pathways described above, including reaction of $\mathrm{CDOM}$ with ${ }^{\circ} \mathrm{OH}$ that is formed in photo-Fenton reactions (Brinkmann et al., 2003a; Molot et al., 2005; White et al., 2003; Xie et al., 2004). Upon photobleaching, the spectral slope $S$ (see Eq. 12 below) of CDOM spectra often increases but also may decrease, depending on the pathway of photobleaching. In the following subsections we discuss in more detail

- Absorption properties of CDOM

- Changes of the spectral slope upon photobleaching of CDOM

- Dependence of CDOM photobleaching on salinity, $\mathrm{pH}$, the presence of iron, and wavelengths

- Penetration depth of solar radiation into water bodies

\section{Absorption properties of CDOM}

CDOM exhibits broad, featureless absorption spectra, decreasing approximately exponentially throughout the ultraviolet and visible wavelength regimes. CDOM spectra have typically been fitted to the expression (Blough and Green, 1995; Davies-Colley and Vant, 1987; Ma and Green, 2004; Stedmon et al., 2000; Twardowski et al., 2004),

$\mathrm{a}(\lambda)=\mathrm{a}\left(\lambda_{0}\right) \mathrm{e}^{-S\left(\lambda-\lambda_{0}\right)}$

where $\mathrm{a}(\lambda)$ and $\mathrm{a}\left(\lambda_{0}\right)$ are the absorption coefficients at wavelength $\lambda$ and reference wavelength $\lambda_{0}$, respectively (typically in $\mathrm{m}^{-1}$ ), and $S$ is the spectral slope, which is a parameter that characterizes how rapidly 
the absorption decreases with increasing wavelength. A refined model for CDOM absorption spectra has been used in several studies (Murphy et al., 2008; Stedmon et al., 2000; Twardowski et al., 2004). The absorption coefficient $\mathrm{a}(\lambda)$ is,

$\mathrm{a}(\lambda)=2.303 \times \mathrm{A}(\lambda) \times \mathrm{r}^{-1}$

where $A(\lambda)$ is the absorbance at wavelength $\lambda$ and $r$ is the path-length (typically in $\mathrm{m}$ ). Studies of marine waters in the eastern Caribbean (Blough et al., 1993) and off the coast of south Florida (Blough and Green, 1995) have found that $S$ is generally larger for oligotrophic "blue" waters $\left(0.02 \mathrm{~nm}^{-1}\right)$ than for coastal "brown" waters $\left(0.013-0.018 \mathrm{~nm}^{-1}\right)$. Values of $S$ for terrestrial sources of CDOM range from 0.01-0.02 $\mathrm{nm}^{-1}$ (Davies-Colley and Vant, 1987; Zepp and Schlotzhauer, 1981). Similarly, more recent studies have found large increases in $S$ in transects from end members dominated by input of terrigenous organic matter, e.g., wetlands and fjords, to marine end members dominated by algal-derived compounds (Helms et al., 2008; Stedmon et al., 2000). Values of $\mathrm{a}(300)$ range from $<0.1 \mathrm{~m}^{-1}$ for "blue" seawaters to $>50 \mathrm{~m}^{-1}$ for some coastal waters and freshwaters (Blough et al., 1993; Green and Blough, 1994; Haag and Hoigné, 1986; Morel et al., 2007).

In many aquatic systems, particularly in freshwater systems, $a(\lambda)$ values are correlated with DOC concentration (Del Vecchio and Blough, 2004a; Molot and Dillon, 1997a; Morris et al., 1995; Pace and Cole, 2002). However, a( $\lambda$ )/DOC ratios may vary to a great extent. For example, Del Vecchio and Blough (2004a) reported that the a(400)/DOC ratio decreased by over an order of magnitude with increasing salinity in the Middle Atlantic Bight, due to (i) different DOC and CDOM content in the freshwater and oceanic end members, and (ii) photobleaching of CDOM in the surface waters of the shelf.

\section{Changes of the spectral slope upon photobleaching of CDOM}

The loss of absorption (i.e., smaller absorption coefficients, $\mathrm{a}(\lambda)$ ) upon CDOM photodegradation is usually greater at longer wavelengths, leading to an increase in the spectral slope $S$ (Blough et al., 1993; Del Vecchio and Blough, 2002; Del Vecchio and Blough, 2004a; Hefner et al., 2006; Helms et al., 2008; Ma and Green, 2004; Minor et al., 2007; Moran et al., 2000; Twardowski and Donaghay, 2002; Vodacek et al., 1995; Vodacek et al., 1997; Xie et al., 2004). However, also decreases in $S$ upon CDOM photobleaching have been observed (Brinkmann et al., 2003a; Gao and Zepp, 1998; Morris and Hargreaves, 1997; White et al., 2003).
An interesting phenomenon is that decreases in $S$ are generally observed when photo-Fenton reactions are likely to be involved in CDOM photobleaching (Brinkmann et al., 2003a; Morris and Hargreaves, 1997; White et al., 2003). White and coworkers (2003) compared ${ }^{\circ} \mathrm{OH}$ production rates (normalized to the absorption coefficient at $350 \mathrm{~nm}$ ) to changes in the spectral slope upon irradiation (with a solar simulator) of water samples from the Satilla River, New Jersey Pine Barrens, Mississippi River Plume, and Florida Keys. Except for the Mississippi River Plume sample (where photolysis of nitrate or nitrite was the likely source of ${ }^{\circ} \mathrm{OH}$ ), they observed a general trend that samples with larger ${ }^{\circ} \mathrm{OH}$ production rates experienced larger decreases in $S$, whereas $S$ values for samples with small ${ }^{\circ} \mathrm{OH}$ production rates, such as the Florida Keys sample, increased upon irradiation. The phenomenon of a decrease in $S$ in photo-Fenton systems may tentatively be interpreted in terms of a shift in the type of chromophores involved, i.e. from ligand-tometal charge-transfer transitions to coupled intramolecular charge-transfer transitions between hydroxy-aromatic donors and quinoid acceptors.

\section{Dependence of CDOM photobleaching on salinity, $\mathrm{pH}$, the presence of iron, and wavelengths}

The environmental factors (salinity, $\mathrm{pH}$, the presence of iron, wavelength of solar radiation) that affect CDOM photobleaching kinetics are interdependent. The extent of CDOM photobleaching generally increases with decreasing salinity (Minor et al., 2006) and pH (Brinkmann et al., 2003a; Molot et al., 2005), possibly reflecting the higher photochemical reactivity of terrestrial-derived CDOM and the importance of photo-Fenton reactions. For example, Brinkmann and coworkers (2003a) found an enhancement of CDOM photobleaching around $\mathrm{pH} 5$ upon addition of iron to water samples from a humic-rich bog lake.

Regarding both the $\mathrm{pH}$ - and wavelength-dependence of CDOM photobleaching, Molot and Dillon (1997b) found that irradiation wavelengths $>320 \mathrm{~nm}$ dominated photobleaching between $\mathrm{pH} 5-7$, whereas below $\mathrm{pH} \mathrm{5}$, the role of UV-B increased. They rationalized these findings in terms of photobeleaching via photo-Fenton reactions occurring most efficiently in acidic waters and under the influence of UV$B$ radiation. Indeed, the apparent quantum yield of $\mathrm{Fe}$ (II) formation has been shown to decrease with increasing wavelength between $300-450 \mathrm{~nm}$ in irradiated lake water samples (pH 7.6) (Emmenegger et al., 2001). Furthermore, formation of ${ }^{\circ} \mathrm{OH}$ (as measured by degradation of atrazine via attack by $\left.{ }^{\circ} \mathrm{OH}\right)$ in homogeneous photo-Fenton systems was found to occur with highest rates between $\mathrm{pH} 4-5$ (in the range $3<\mathrm{pH}<8$ ) (Balmer and Sulzberger, 1999), which was 
mainly due to different photolysis efficiencies of the pH-dependent Fe(III) species. From the above discussion, it seems thus reasonable to assume that UV-B radiation is particularly effective in CDOM photobleaching in acidic, iron-rich aquatic systems.

Penetration depth of solar radiation into water bodies The penetration depth of solar radiation into water bodies can be calculated on the basis of measured diffuse attenuation coefficients, $\mathrm{K}_{\mathrm{d}}$, and considering Beer-Lambert's law,

$\log _{\frac{W}{W_{z}(\lambda)}}=K_{d}(\lambda) \times z$

where $\mathrm{z}$ is the depth of a water body (in $\mathrm{m}$ ), $\mathrm{W}(\lambda)$ and $\mathrm{W}_{\mathrm{z}}(\lambda)$ are the photon flux at the surface and at depth $\mathrm{z}$, respectively (usually in einstein $\mathrm{m}^{-2} \mathrm{~s}^{-1} \mathrm{~nm}^{-1}$ ), and $\mathrm{K}_{\mathrm{d}}$ $(\lambda)$ is the diffuse attenuation coefficient at wavelength $\lambda\left(\right.$ in $\left.^{-1}\right)$. The depth at which only $1 \%$ of the incident photon flux at wavelength $\lambda$ is transmitted is then,

$\mathrm{Z}_{1 \%}(\lambda)=4.606 \times \mathrm{K}_{\mathrm{d}}(\lambda)^{-1}$

Diffuse attenuation coefficients are determined from the slope of the linear regression of the natural logarithm of downwelling solar irradiance vs. depth z. In lakes, attenuation depths $\left(\mathrm{z}_{1 \%}\right)$ for UV-B (e.g., at $305 \mathrm{~nm}$ ) range from several centimeters to $\sim 10 \mathrm{~m}$ (Morris et al., 1995), whereas in clear open ocean waters, $\mathrm{z}_{1 \%}(310 \mathrm{~nm})$ values $>60 \mathrm{~m}$ have been measured (Morel et al., 2007).

Photobleaching of CDOM affects the penetration depth of solar radiation. Reche and coworkers (1999) found a significant positive relationship between photobleaching rate coefficients, $\mathrm{k}_{\mathrm{b}}$, and $\mathrm{z}_{1 \%}$ for photosynthetic active radiation $(400-700 \mathrm{~nm})$ in their studied lakes. Photobleaching rate coefficients, $\mathrm{k}_{\mathrm{b}}$ were determined from the slope of ln-linear regressions according to a first-order kinetics expression,

$\mathrm{a}(\lambda)_{\mathrm{t}}=\mathrm{a}(\lambda)_{0} \mathrm{e}^{-\mathrm{k}_{\mathrm{b}}(\lambda) \mathrm{D}_{\mathrm{c}}}$

where $\mathrm{a}(\lambda)_{\mathrm{t}}$ and $\mathrm{a}(\lambda)_{0}$ are the absorption coefficient at a given wavelength at time $t$ and time 0 , respectively (in $\mathrm{m}^{-1}$ ), $\mathrm{k}_{\mathrm{b}}(\lambda)$ is the photobleaching rate coefficient at a given wavelength (in $\mathrm{m}^{2}$ einstein ${ }^{-1}$ ), and $\mathrm{D}_{\mathrm{c}}$ is the cumulative sunlight dose, $\mathrm{D}_{\mathrm{c}}=\int_{\lambda} \mathrm{W}(\lambda) \mathrm{d} \lambda \mathrm{x} \mathrm{t}$ (in einstein $\mathrm{m}^{-2}$ ). Since the kinetics of CDOM photobleaching depends on the intensity of solar radiation, $\mathrm{K}_{\mathrm{d}}(\lambda)$ and $\mathrm{z}_{1 \%}(\lambda)$ are expected to vary seasonally. Morris and Hargreaves (1997) observed highest $K_{d}$ values (lowest transparency) at $320 \mathrm{~nm}$ in early spring and again in late fall in three Pocono Plateau lakes.
The half-life of light absorption by CDOM at a given wavelength can be expressed as

$\mathrm{t}_{1 / 2}=\frac{\ln 2}{\mathrm{k}_{\mathrm{b}}(\lambda) \mathrm{D}}$

where $\mathrm{D}$ is the sunlight dose, $\mathrm{D}=\int_{\lambda} \mathrm{W}(\lambda) \mathrm{d} \lambda$ (in einstein $\mathrm{m}^{-2} \mathrm{~s}^{-1}$ ). Reche and coworkers (2000) assessed half-lives of light absorption by CDOM (i.e., the time to reduce light absorption at 320 and $440 \mathrm{~nm}$ by $50 \%$ ) in two model lakes, one situated in the northern hemisphere ( $\mathrm{NH}$, Institute of Ecosystem Studies, Millbrook, USA) and the other in the southern hemisphere ( $\mathrm{SH}$, Ushuaia, Argentina). For the $\mathrm{NH}$ site, the half-life at $440 \mathrm{~nm}$ was 6.6 and $342 \mathrm{~d}$ for $\mathrm{DOC}=0.3$ and $30 \mathrm{mg} \mathrm{L}^{-1}$, respectively, while that for the $\mathrm{SH}$ site ranged from $1.2-103 \mathrm{~d}$ for similar DOC concentrations. The half-life at $320 \mathrm{~nm}$ was 5-8 times smaller in the $\mathrm{SH}$ than in the $\mathrm{NH}$ site, depending on DOC concentration. These findings were interpreted in terms of CDOM photobleaching being strongly dependent on the intensity and wavelength of solar radiation (see previous subsection).

\section{Effects of UV radiation on the bioavailability and mineralization of DOM}

The bioavailability of DOM largely depends on its origin, thus chemical composition, and diagenetic alteration. UV-induced transformations of DOM can increase or decrease the bioavailability of DOM, depending on the initial bioavailability and subsequent transformation pathways. UV-induced changes of DOM bioavailability might heavily affect microbial DOM mineralization. Furthermore, mineralization of DOM also occurs as an abiotic, UV-induced process. These items are discussed in the following subsections.

\section{Origin, chemical composition and bioavailability of DOM}

The bioavailability (or bioreactivity) of DOM depends on its chemical composition and thus its origin. Algal-derived DOM has been reported to be biologically more labile than terrigenous DOM (Bertilsson and Jones, 2003; Biddanda and Cotner, 2003; Boyd and Osburn, 2004; Chen et al., 2004; Davis and Benner, 2007; Kaiser et al., 2004; Karlsson et al., 2007; McCallister et al., 2006; Obernosterer and Benner, 2004; Perez and Sommaruga, 2006; Tranvik and Bertilsson, 2001; Vähätalo and Wetzel, 2004). Likely reasons for this phenomenon are the following: (i) autochthonous DOM is enriched in carbohydrates, and (ii) the $\mathrm{C} / \mathrm{N}$ ratio of plankton and bacteria is much smaller than that of vascular plant tissues (Aluwihare 
et al., 2002; Benner et al., 1992; Ertel et al., 1986; Hedges et al., 1986; Hedges et al., 1994; Hedges et al., 2000; Hopkinson et al., 1998; Kaiser et al., 2004; McCallister et al., 2006; McKnight et al., 1991) (see subsection "Bulk characterization of DOM").

The bioavailability of DOM also depends on its polydispersity. Amon and Benner (1994; 1996a) reported that HMW DOM was utilized to a greater extent by bacterioplankton than LMW DOM, both in freshwater and seawater samples. These authors (1996a) proposed a conceptual model whereby the bioreactivity of DOM decreases along a continuum of size (from large to small). A number of studies have directly or indirectly corroborated this size-continuum model (Benner et al., 1997; Hernes and Benner, 2006; Kim et al., 2006; McCallister et al., 2006; Repeta and Aluwihare, 2006; Scully et al., 2004; Seitzinger et al., 2005).

Kaiser and Sulzberger (2004) found, on the other hand, that LMW and hydrophilic compounds collected from the Tagliamento River (a semi-natural, oligotrophic alpine river in northeast Italy) exhibited a higher bioreactivity than HMW and hydrophobic DOM compounds from this river. In this riverine system, HMW and hydrophobic components are derived from the leaching of soils that contain highly altered plant material and bacterial biomass, whereas highly bioavailable LMW and hydrophilic components are likely derived from the decomposition of diagenetically young fine particulate organic matter (FPOM) and autochthonous microalgae biomass. An interesting phenomenon reported by Kaiser and Sulzberger (2004), which points to Amon and Benner's (1996a) continuum size model was the following: Size exclusion chromatograms of LMW and HMW DOM fractions from the Tagliamento River before and after incubation with riverine bacterioplankton revealed that the riverine bacteria utilized and released compounds at the high and low end, respectively, of the apparent molecular weight distribution of these fractions.

According to Amon and Benner's (1996a) continuum model, the bioavailability of DOM also decreases along a continuum of diagenetic state (from fresh to old). Heterotrophic bacteria preferentially utilize carbohydrate- and protein-carbon from fragments of plants and microbial tissues (Baldock et al., 2004), carbohydrate-, protein-, and lignin-carbon from partially decomposed residues (Baldock et al., 2004; Ertel et al., 1986; Frazier et al., 2005; Hernes and Benner, 2006), resulting in the formation of biorecalcitrant chemical structures that are dominated by alkyl C (Baldock et al., 2004; Smittenberg et al., 2006). Hence microbial transformations and release of organic compounds as well as bacterial remnants can contribute significantly to the pool of highly processed, biorecalcitrant DOM in marine systems (Baldock et al., 2004; Ogawa et al., 2001).

\section{UV-induced changes of the bioavailability of DOM}

Several studies have shown that direct or indirect ('OH-mediated) phototransformations of DOM enhance its bioavailability (Bertilsson and Tranvik, 1998; Bertilsson et al., 1999; Brinkmann et al., 2003b; Goldstone et al., 2002; Herndl et al., 1997; Jorgensen et al., 1998; Kieber et al., 1989; Lindell et al., 1995; Mopper et al., 1991; Moran et al., 2000; Pullin et al., 2004; Reche et al., 1998; Scully et al., 2003; Vähätalo et al., 2003; Vähätalo and Wetzel, 2008; Wetzel et al., 1995). This UV-mediated increase in DOM bioavailability can be due to the following combined effects: (i) UV-induced formation of oxygen-rich compounds (Kim et al., 2006; Kujawinski et al., 2004; Kulovaara et al., 1996), (ii) UV-induced increase in the concentration of amino acids and carbohydrates (Jørgensen et al., 1998; Nieto-Cid et al., 2006), which are dominant energy sources to bacteria (Baldock et al., 2004; Benner, 2003; Jørgensen et al., 1998; Nieto-Cid et al., 2006; Repeta and Aluwihare, 2006; Simon and Rosenstock, 2007), and (iii) UV-induced formation of LMW compounds, e.g., carbonyl compounds and carboxylic acids including formic, acetic, pyruvic, oxalic, malonic, and succinic acids (Bertilsson and Tranvik, 1998; Bertilsson et al., 1999; Brinkmann et al., 2003b; Corin et al., 1996; Frimmel, 1998; Goldstone et al., 2002; Kieber et al., 1989; Kieber et al., 1990; Kujawinski et al., 2004; Moran and Zepp, 1997; Obernosterer et al., 1999a; Pullin et al., 2004; Wetzel et al., 1995).

The observation that UV-induced break-down of DOM into LMW compounds increases DOM bioavailability seems to be in contradiction with the continuum-size model by Amon and Benner (1996a) (see above). Obviously, whether UV-induced formation of LMW compounds results in an increase or decrease in DOM bioavailability largely depends on the bioavailability of the initial compounds and on the transformation pathways. LMW compounds that are highly processed both by biotic and abiotic reactions, may be extremely recalcitrant (Amon and Benner, 1994; Baldock et al., 2004; Kawasaki and Benner, 2006; Ogawa et al., 2001). For example, Pullin and coworkers (2004) reported that LMW compounds could not account for most of the observed sunlight and $\mathrm{OH}$-induced increases in DOM bioavailability.

There are an increasing number of studies showing contrasting effects of UV-induced transformations on DOM bioavailability, transforming bioavailable into biorecalcitrant compounds and vice-versa (Benner and Biddanda, 1998; Biddanda and Cotner, 2003; 

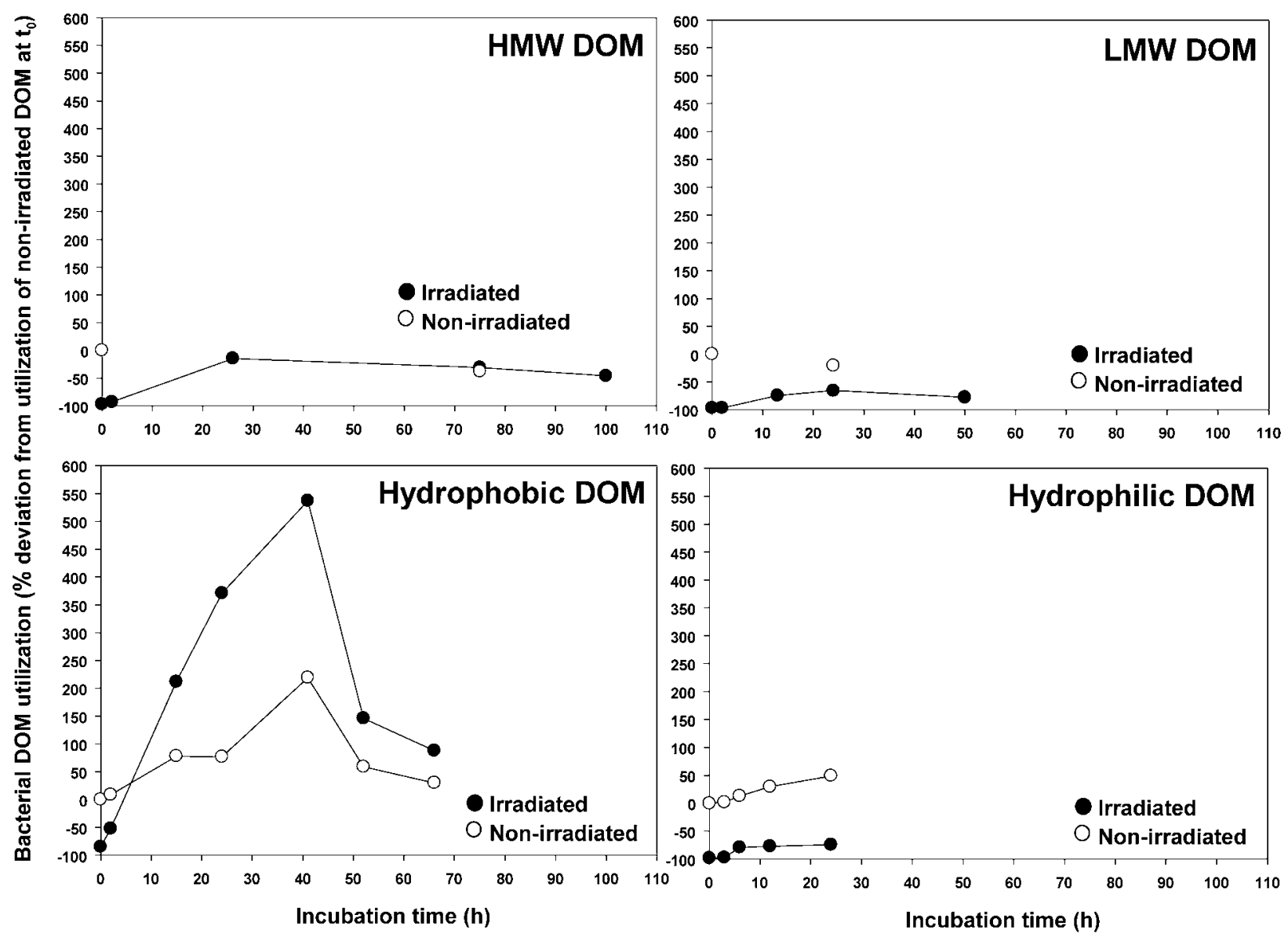

Figure 6. Long-term bioassay experiments on irradiated (filled circles) and non-irradiated (open circles) DOM fractions sampled during April 2000 in the Tagliamento River (Italy): (A) HMW, (B) LMW, (C) hydrophobic, and (D) hydrophilic DOM. Bacterial DOM utilization is based on measurements of bacterial biomass production ( $\left.\mathrm{fg} \mathrm{Cell}{ }^{-1} \mathrm{~d}^{-1}\right)$. Changes in bacterial DOM utilization were calculated as \% deviation of utilization of non-irradiated DOM before long-term incubation (modified from Kaiser and Sulzberger, 2004).

Judd et al., 2007; Kaiser and Sulzberger, 2004; Obernosterer et al., 1999b; Obernosterer and Benner, 2004; Tranvik and Bertilsson, 2001). Kaiser and Sulzberger (2004) found that photochemical transformations decreased the bioavailability of initially bioreactive LMW and hydrophilic compounds from the Tagliamento River, whereas the bioavailability of initially biorecalcitrant hydrophobic compounds increased upon irradiation, while that of HMW compounds did not change (Fig. 6).

UV-induced transformations often have a positive effect on the bioavailability of terrigenous DOM, while the bioavailability of autochthonous DOM is less positively affected or even decreases (Biddanda and Cotner, 2003; Judd et al., 2007; Kaiser and Sulzberger, 2004; Obernosterer and Benner, 2004; Reche et al., 1998; Tranvik and Bertilsson, 2001). The former may be rationalized by allochthonous DOM becoming more like autochthonous DOM upon UVinduced transformations (in terms of chemical composition) (Dittmar et al., 2007; Minor et al., 2007; Tremblay et al., 2007). UV-induced transformations have been shown to be particularly efficient in increasing the bioavailability of terrigenous DOM if it is diagenetically highly altered and vice versa (Benner and Biddanda, 1998; Biddanda and Cotner, 2003; Kaiser and Sulzberger, 2004; Obernosterer et al., 1999b). These findings are in agreement with the model by Amon and Benner (1996a) according to which the bioreactivity of DOM decreases along a continuum of diagenetic state. In marine and lacustrine systems, the concentration of diagenetically old DOM, i.e., of biorefractory DOM compounds, increases with depth, and UV-induced transformations of surface and deep water DOM have been shown to decrease and increase DOM bioavailability, respectively (Benner and Biddanda, 1998; Biddanda and Cotner, 2003; Obernosterer et al., 1999b).

\section{Mineralization of DOM}

In both photomineralization and microbial respiration of DOM (oxidation of DOM to $\mathrm{CO}_{2}, \mathrm{H}_{2} \mathrm{O}$, and major and minor nutrients), molecular oxygen $\left(\mathrm{O}_{2}\right)$ is consumed and $\mathrm{CO}_{2}$ is produced. The ratio of $\mathrm{DOC}$ loss 
to $\mathrm{O}_{2}$ consumed or $\mathrm{CO}_{2}$ produced in DOM photomineralization has been reported to be around one in various aquatic systems (Amon and Benner, 1996b; Kortzinger et al., 2001; Xie et al., 2004). The rate of DOM photomineralization increases with decreasing pH (Anesio and Granéli, 2004) and also depends on the precipitation regime (Clark et al., 2004; Rodriguez-Zuniga et al., 2008). In marine systems, it also depends upon sea ice cover (Bélanger et al., 2006). These authors predict that ongoing reduction in the extent of sea ice cover will greatly accelerate photomineralization of terrigenous DOM in Arctic surface waters. Furthermore, UV-induced mineralization of above-ground litter may result in a substantial fraction of carbon fixed in plant biomass being lost directly to the atmosphere (Austin and Vivanco, 2006).

The question about the fate of terrigenous DOM in the oceans has puzzled and still puzzles biogeochemists. Terrigenous DOM comprises only a small fraction $(0.7-2.4 \%)$ of the total DOM in the ocean (Opsahl and Benner, 1997). A large fraction of terrigenous DOM introduced into open ocean waters must be mineralized in estuarine and coastal waters, where photomineralization plays a prominent role (Amon and Benner, 1996b; Bélanger et al., 2006; Del Vecchio and Blough, 2004a; Hansell et al., 2004; Hedges et al., 1997; Hernes and Benner, 2003; Kowalczuk et al., 2005; Minor et al., 2007; Opsahl and Benner, 1998; Rodriguez-Zuniga et al., 2008; Stabenau and Zika, 2004; Vähätalo and Wetzel, 2004). Studies on the halflife of terrigeneous compounds within the bulk DOM pool show that their mineralization is relatively fast, being within the range of 7 years (Hansell et al., 2004), and ocean residence times fall between 20 to 130 years (Opsahl and Benner, 1997). Hence, photomineralization processes, especially in the coastal ocean, may be important next to microbial consumption and may even become of increasing importance due to climatedriven loss of sea-ice cover in arctic regions.

\section{Conclusions}

The molecular-level elucidation of the chemical composition of DOM has greatly helped to elucidate UV-effects on the chemical composition and thus optical properties and bioavailability of DOM. It also has enabled the prediction of how the photo- and bioreactivity depend on DOM origin. Such information is needed to model the global carbon cycle, particularly with respect to consequences of climate change. We believe that further sophistication of analytical tools and intelligent combinations of methods will continue to improve our understanding of the chemical composition, structure, conformation, opti- cal, and redox properties of DOM and how they control DOM photo- and bioreactivity (Fan et al., 2000; Fimmen et al., 2007; Hertkorn et al., 2006; Paul et al., 2006; Schmitt-Kopplin et al., 1998a; Schulten and Schnitzer, 1997; Simjouw et al., 2005). For example, the study by Hertkorn et al. (2006), involving a combination of NMR, capillary electrophoresis (Schmitt-Kopplin et al., 1998b), and FT-ICR-MS, is one of the promising analytical approaches to decipher what is referred to as molecularly uncharacterized carbon (Hatcher, 2004; Hedges et al., 2000). Furthermore, for the elucidation of light-induced processes on a molecular basis, time-resolved spectroscopic methods are needed, which so far have been applied in only a few environmental-photochemical studies (Bruccoleri et al., 1993; Del Vecchio and Blough, 2004b; Wang et al., 2007b).

In assessing UV-induced changes of the chemical composition of DOM and thus of carbon cycling, the role of climate change also has to be taken into account (Zepp et al., 2007) (Fig. 7). Climate change includes warming and, as a consequence, reduction in sea ice cover and stratification of aquatic systems (Behrenfeld et al., 2006; Zepp et al., 2007 and refs. cited therein), ocean acidification (Caldeira and Wickett, 2003; Doney, 2006), and changes in continental hydrology (Zepp et al., 2007 and refs. cited therein). Increasing temperatures and changes in the frequency and intensity of precipitations can enhance the discharge of DOM from terrestrial into aquatic systems (Freeman et al., 2001; Mack et al., 2004; Peterson et al., 2002). As discussed above, terrigenous DOM exhibits a greater photoreactivity than autochthonous DOM, and UV-induced transformations of terrigenous DOM generally increase its bioavailability and, in turn, microbial respiration (Bertilsson and Tranvik, 1998; Obernosterer and Benner, 2004; Pullin et al., 2004). Furthermore, terrigenous DOM also is subject to photomineralization (Bélanger et al., 2006). Hence, the result of UV radiation and changes in continental hydrology could be a net loss of organic carbon from terrestrial ecosystems and a UV-mediated positive feedback to $\mathrm{CO}_{2}$ accumulation in the atmosphere (Zepp et al., 2007 and refs. cited therein) (Fig. 7). Boreal wetlands in the Arctic, where increased UV radiation and reduction in sea ice cover are more pronounced, are particularly sensitive to such UV-induced feedback mechanisms (Bélanger et al., 2006; Zepp et al., 2007 and refs. cited therein).

Increased stratification of lakes and oceans enhance UV-induced CDOM bleaching (Chen et al., 2007; Del Vecchio and Blough, 2002; Del Vecchio and Blough, 2004a; Vodacek et al., 1997). Stratification also reduces the transport of UV-absorbing compounds from deeper water into the euphotic zone, thus 


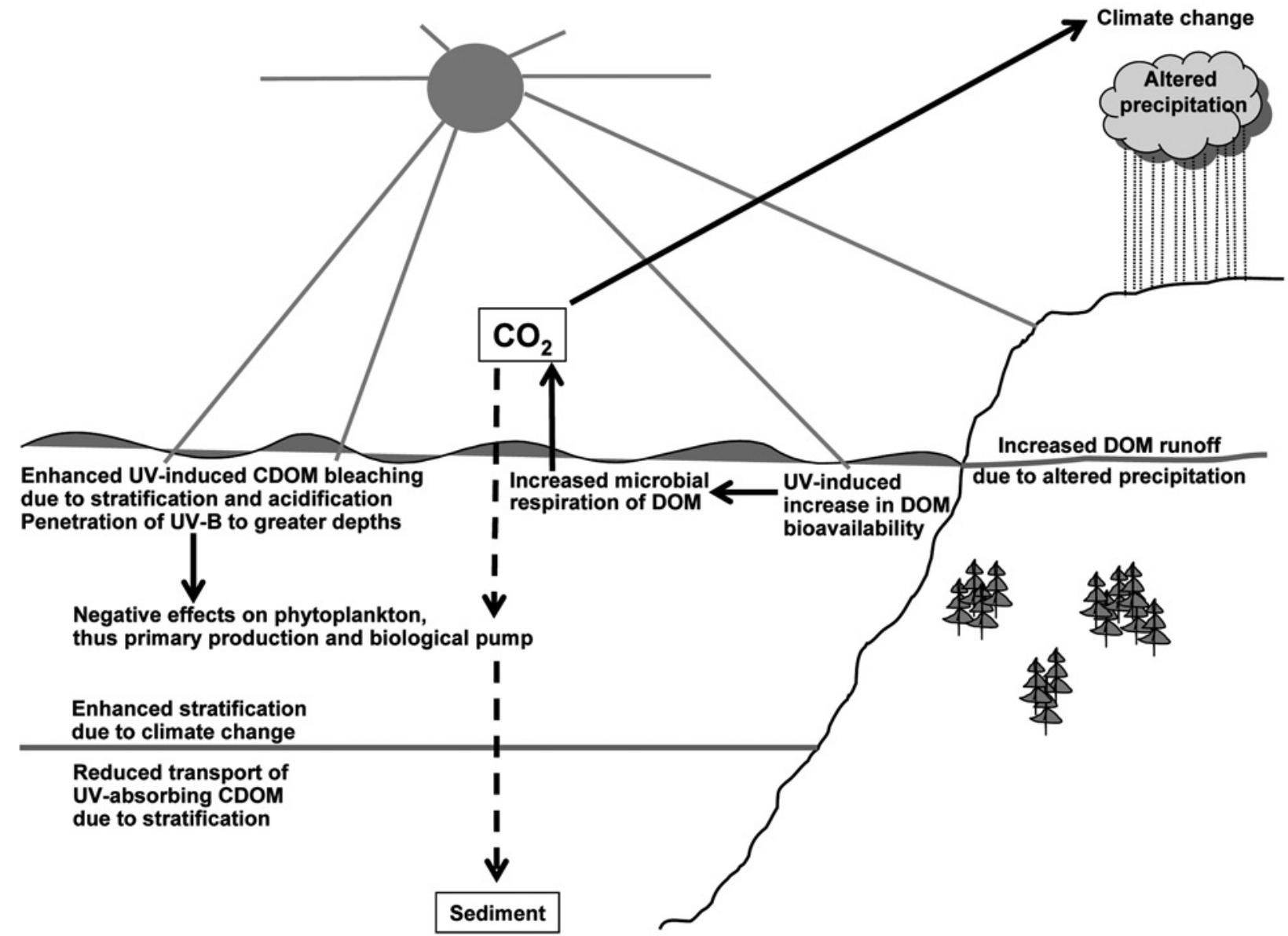

Figure 7. Potential combined effects of UV radiation and climate change on aquatic source (solid arrows) and sink (dashed arrows) terms of atmospheric $\mathrm{CO}_{2}$. In this simplified scheme, only microbial respiration of DOM and the biological pump are considered as an aquatic source and sink, respectively, of atmospheric $\mathrm{CO}_{2}$.

worsening the effects of CDOM photobleaching on UV-B penetration (Zepp et al., 2007 and refs. cited therein). Also, decreasing $\mathrm{pH}$ values of oceans and freshwater systems due to increased atmospheric $\mathrm{CO}_{2}$ concentrations (Caldeira and Wickett, 2003; Doney, 2006) may enhance UV-induced bleaching of CDOM (see subsection "Dependence of CDOM photobleaching on $\mathrm{pH}$ and wavelength") and hence increase UV penetration into water bodies. UV-B-induced damages of the phytoplankton in the oceans is critical since the global ocean plays a major role in carbon sequestration (Behrenfeld et al., 2006; Mikaloff Fletcher et al., 2006), where the biological pump (photosynthesis by phytoplankton and subsequent sedimentation of a fraction of phytoplankton residues) plays a key role (Buesseler et al., 2007). UV-Binduced damages to phytoplankton could render the biological pump less effective and hence $\mathrm{CO}_{2}$-related ocean acidification could represent another UVmediated positive feedback mechanism of $\mathrm{CO}_{2}$ accumulation in the atmosphere (Fig. 7).

\section{Acknowledgments}

We thank Thomas Brinkmann, Philip Hörsch, Daniel Sartorius and Fritz H. Frimmel for allowing us to reproduce a figure from their article "Photoformation of Low-Molecular-Weight Organic Acids from Brown Water Dissolved Organic Matter" (see Brinkmann et al., 2003b). We also reproduced a figure from Meunier et al. (2005), and we would like to acknowledge the Swiss Government (Bundesamt für Bildung und Wissenschaft) for the financial support of the project published in this paper, which was part of the EUProject COMET (Composition of Dissolved Organic Matter and its Interactions with Metals and Ultraviolet Radiation in River-Ocean Systems: Impact on the Microbial Food Web). 


\section{References}

Abrahamson, H. B., A. B. Rezvani and J. G. Brushmiller, 1994. Photochemical and spectroscopic studies of complexes of iron(III) with citric acid and other carboxylic acids. Inorganica Chimica Acta 226: 117 - 127.

Algesten, G., S. Sobek, A. K. Bergstrom, A. Agren, L. J. Tranvik and M. Jansson, 2004. Role of lakes for organic carbon cycling in the boreal zone. Global Change Biology 10: 141 - 147.

Aluwihare, L. I., D. J. Repeta and R. F. Chen, 2002. Chemical composition and cycling of dissolved organic matter in the Mid-Atlantic Bight. Deep-Sea Research Part II-Topical Studies in Oceanography 49: 4421 - 4437.

Amon, R. M. W. and R. Benner, 1994. Rapid cycling of highmolecular-weight dissolved organic matter in the ocean. Nature 369: 549 - 552 .

Amon, R. M. W. and R. Benner, 1996a. Bacterial utilization of different size classes of dissolved organic matter. Limnology and Oceanography 41: $41-51$.

Amon, R. M. W. and R. Benner, 1996b. Photochemical and microbial consumption of dissolved organic carbon and dissolved oxygen in the Amazon River system. Geochimica et Cosmochimica Acta 60: $1783-1792$.

Anesio, A. M. and W. Granéli, 2004. Photochemical mineralization of dissolved organic carbon in lakes of differing $\mathrm{pH}$ and humic content. Archiv für Hydrobiologie 160: 105 - 116.

Anthony, K. R. N., S. R. Connolly and O. Hoegh-Guldberg, 2007. Bleaching, energetics, and coral mortality risk: Effects of temperature, light, and sediment regime. Limnology and Oceanography 52: 716 - 726.

Anthony, K. R. N. and A. P. Kerswell, 2007. Coral mortality following extreme low tides and high solar radiation. Marine Biology 151: 1623 - 1631 .

Ashcroft, A. E., 1997. Ionization Methods in Organic Mass Spectrometry, Analytical Monograph, Royal Society of Chemistry, UK.

Austin, A. T. and L. Vivanco, 2006. Plant litter decomposition in a semi-arid ecosystem controlled by photodegradation. Nature 442: $555-558$.

Baldock, J. A., C. A. Masiello, Y. Gelinas and J. I. Hedges, 2004. Cycling and composition of organic matter in terrestrial and marine ecosystems. Marine Chemistry 92: $39-64$.

Balmer, M. E. and B. Sulzberger, 1999. Atrazine degradation in irradiated iron oxalate systems: Effects of $\mathrm{pH}$ and oxalate. Environmental Science and Technology 33: $2418-2424$.

Battin, T. J., 1998. Dissolved organic matter and its optical properties in a blackwater tributary of the upper Orinoco river, Venezuela. Organic Geochemistry 28: $561-569$.

Beardall, J. and J. A. Raven, 2004. The potential effects of global climate change on microalgal photosynthesis, growth and ecology. Phycologia 43: 26 - 40.

Behrenfeld, M. J., R. T. O’Malley, D. A. Siegel, C. R. Mcclain, J. L. Sarmiento, G. C. Feldman, A. J. Milligan, P. G. Falkowski, R. M. Letelier and E. S. Boss, 2006. Climate-driven trends in contemporary ocean productivity. Nature 444: $752-755$.

Bélanger, S., H. X. Xie, N. Krotkov, P. Larouche, W. F. Vincent and M. Babin, 2006. Photomineralization of terrigenous dissolved organic matter in Arctic coastal waters from 1979 to 2003: Interannual variability and implications of climate change. Global Biogeochemical Cycles 20: doi 10.1029/2006GB002708.

Benner, R., J. D. Pakulski, M. McCarthy, J. I. Hedges and P. G. Hatcher, 1992. Bulk chemical characteristics of dissolved organic matter in the ocean. Science 255: $1561-1564$.

Benner, R., B. Biddanda, B. Black and M. McCarthy, 1997. Abundance, size distribution, and stable carbon and nitrogen isotopic compositions of marine organic matter isolated by tangential-flow ultrafiltration. Marine Chemistry 57: $243-$ 263.

Benner, R. and B. Biddanda, 1998. Photochemical transformations of surface and deep marine dissolved organic matter: Effects on bacterial growth. Limnology and Oceanography 43: 1373 1378.
Benner, R., 2003. Molecular indicators of the bioavailability of dissolved organic matter. In: S. E. G. Findlay and R. L. Sinsabaugh (eds.), Aquatic Ecosystems: Interactivity of Dissolved Organic Matter, Academic Press, pp. 121 - 137.

Bertilsson, S. and L. J. Tranvik, 1998. Photochemically produced carboxylic acids as substrates for freshwater bacterioplankton. Limnology and Oceanography 43: $885-895$.

Bertilsson, S., R. Stepanauskas, R. Cuadros-Hansson, W. Granéli, J. Wikner and L. Tranvik, 1999. Photochemically induced changes in bioavailable carbon and nitrogen pools in a boreal watershed. Aquatic Microbial Ecology 19: 47 - 56.

Bertilsson, S. and J. L. Jones, 2003. Supply of dissolved organic matter to aquatic ecosystems: Autochthonous sources. In: S. E. G. Findlay and R. L. Sinsabaugh (eds.), Aquatic Ecosystems: Interactivity of Dissolved Organic Matter, Academic Press, pp. $3-25$.

Biddanda, B. A. and J. B. Cotner, 2003. Enhancement of dissolved organic matter bioavailability by sunlight and its role in the carbon cycle of Lakes Superior and Michigan. Journal of Great Lakes Research 29: 228 - 241.

Biers, E. J., R. G. Zepp and M. A. Moran, 2007. The role of nitrogen in chromophoric and fluorescent dissolved organic matter formation. Marine Chemistry 103: $46-60$.

Blough, N. V., O. C. Zafiriou and J. Bonilla, 1993. Optical absorption spectra of waters from the Orinoco River outflow: Terrestrial input of colored organic matter to the Caribbean. Journal of Geophysical Research Oceans 98: 2271 - 2278.

Blough, N. V. and S. A. Green, 1995. Spectroscopic characterization and remote sensing of nonliving organic matter. In: R. G. Zepp and C. Sonntag (eds.), Role of Nonliving Organic Matter in the Earth's Carbon Cycle, John Wiley \& Sons. Ltd., pp. 23 - 45.

Blough, N. V. and R. G. Zepp, 1995. Reactive oxygen species in natural waters. In: C. S. Foote, J. S. Valentine, A. Greenberg and J. F. Liebman (eds.), Active Oxygen Species in Chemistry, Blackie Academic and Professional, pp. 280 - 333.

Boehme, J., P. Coble, R. Conmy and A. Stovall-Leonard, 2004. Examining CDOM fluorescence variability using principal component analysis: seasonal and regional modeling of threedimensional fluorescence in the Gulf of Mexico. Marine Chemistry 89: $3-14$.

Borer, P., S. J. Hug, B. Sulzberger, S. M. Kraemer and R. Kretzschmar, 2007. Photolysis of citrate on the surface of lepidocrocite: An in situ ATR-FTIR study. Journal of Physical Chemistry C 111: 10560 - 10569.

Boyd, T. J. and C. L. Osburn, 2004. Changes in CDOM fluorescence from allochthonous and autochthonous sources during tidal mixing and bacterial degradation in two coastal estuaries. Marine Chemistry 89: $189-210$.

Bracchini, L., A. Cozar, A. M. Dattilo, S. A. Loiselle, A. Tognazzi, N. Azza and C. Rossi, 2006. The role of wetlands in the chromophoric dissolved organic matter release and its relation to aquatic ecosystems optical properties. A case of study: Katonga and Bunjako Bays (Victoria Lake; Uganda). Chemosphere 63: 1170 - 1178.

Brinkmann, T., D. Sartorius and F. H. Frimmel, 2003a. Photobleaching of humic rich dissolved organic matter. Aquatic Sciences 65: $415-424$.

Brinkmann, T., P. Horsch, D. Sartorius and F. H. Frimmel, 2003 b. Photoformation of low-molecular-weight organic acids from brown water dissolved organic matter. Environmental Science and Technology 37: 4190 - 4198.

Brown, A., D. M. McKnight, Y. P. Chin, E. C. Roberts and M. Uhle, 2004. Chemical characterization of dissolved organic material in Pony Lake, a saline coastal pond in Antarctica. Marine Chemistry 89: $327-337$.

Bruccoleri, A., B. C. Pant, D. K. Sharma and C. H. Langford, 1993. Evaluation of primary photoproduct quantum yields in fulvic acid. Environmental Science and Technology 27: 889 - 894.

Buesseler, K. O., C. H. Lamborg, P. W. Boyd, P. J. Lam, T. W. Trull, R. R. Bidigare, J. K. B. Bishop, K. L. Casciotti, F. Dehairs, M. Elskens, M. Honda, D. M. Karl, D. A. Siegel, M. W. Silver, D. K. Steinberg, J. Valdes, B. Van Mooy and S. Wilson, 2007. 
Revisiting carbon flux through the ocean's twilight zone. Science 316: 567 - 570 .

Caldeira, K. and M. E. Wickett, 2003. Anthropogenic carbon and ocean $\mathrm{pH}$. Nature 425: $365-365$.

Cauwet, G., 2002. DOM in the coastal zone. In: D. A. Hansell and C. A. Carlson (eds.), Biogochemistry of Marine Dissolved Organic Matter, Academic Press, pp. 579 - 609.

Chen, R. F., P. Bissett, P. Coble, R. Conmy, G. B. Gardner, M. A. Moran, X. C. Wang, M. L. Wells, P. Whelan and R. G. Zepp, 2004. Chromophoric dissolved organic matter (CDOM) source characterization in the Louisiana Bight. Marine Chemistry 89: $257-272$.

Chen, Z., C. Hu, R. N. Conmy, F. Muller-Karger and P. Swarzenski, 2007. Colored dissolved organic matter in Tampa Bay, Florida. Marine Chemistry 104: $98-109$.

Chin, Y. P., G. Aiken and E. Oloughlin, 1994. Molecular weight, polydispersity, and spectroscopic properties of aquatic humic substances. Environmental Science and Technology 28: 1853 1858.

Clair, T. A. and B. G. Sayer, 1997. Environmental variability in the reactivity of freshwater dissolved organic carbon to UV-B. Biogeochemistry 36: 89 - 97.

Clark, C. D., W. T. Hiscock, F. J. Millero, G. Hitchcock, L. Brand, W. L. Miller, L. Ziolkowski, R. F. Chen and R. G. Zika, 2004. $\mathrm{CDOM}$ distribution and $\mathrm{CO}_{2}$ production on the southwest Florida shelf. Marine Chemistry 89: $145-167$.

Coble, P. G., S. A. Green, N. V. Blough and R. B. Gagosian, 1990. Characterization of dissolved organic-matter in the Black-Sea by fluorescence spectroscopy. Nature 348: $432-435$.

Coble, P. G., 2007. Marine optical biogeochemistry: The chemistry of ocean color. Chemical Reviews 107: $402-418$.

Conmy, R. N., P. G. Coble, R. F. Chen and G. B. Gardner, 2004. Optical properties of colored dissolved organic matter in the Northern Gulf of Mexico. Marine Chemistry 89: 127 - 144 .

Cook, R. L., 2004. Coupling NMR to NOM. Analytical and Bioanalytical Chemistry 378: $1484-1503$.

Corin, N., P. Backlund and M. Kulovaara, 1996. Degradation products formed during UV-irradiation of humic waters. Chemosphere 33: $245-255$.

Cory, R. M. and D. M. McKnight, 2005. Fluorescence spectroscopy reveals ubiquitous presence of oxidized and reduced quinones in dissolved organic matter. Environmental Science and Technology 39: 8142 - 8149 .

Daniel, C., W. Granéli, E. S. Kritzberg and A. M. Anesio, 2006. Stimulation of metazooplankton by photochemically modified dissolved organic matter. Limnology and Oceanography 51: $101-108$.

Davies-Colley, R. J. and W. N. Vant, 1987. Absorption of light by yellow substance in freshwater lakes. Limnology and Oceanography 32: $416-425$.

Davis, J. and R. Benner, 2007. Quantitative estimates of labile and semi-labile dissolved organic carbon in the western Arctic Ocean: A molecular approach. Limnology and Oceanography 52: $2434-2444$.

Del Vecchio, R. and N. V. Blough, 2002. Photobleaching of chromophoric dissolved organic matter in natural waters: kinetics and modeling. Marine Chemistry 78: $231-253$.

Del Vecchio, R. and N. V. Blough, 2004a. Spatial and seasonal distribution of chromophoric dissolved organic matter and dissolved organic carbon in the Middle Atlantic Bight. Marine Chemistry 89: 169 - 187.

Del Vecchio, R. and N. V. Blough, 2004b. On the origin of the optical properties of humic substances. Environmental Science and Technology 38: $3885-3891$.

Dittmar, T., N. Hertkorn, G. Kattner and R. J. Lara, 2006. Mangroves, a major source of dissolved organic carbon to the oceans. Global Biogeochemical Cycles 20.

Dittmar, T., K. Whitehead, E. C. Minor and B. P. Koch, 2007. Tracing terrigenous dissolved organic matter and its photochemical decay in the ocean by using liquid chromatography/ mass spectrometry. Marine Chemistry 107: 378 - 387.
Doney, S. C., 2006. The dangers of ocean acidification. Scientific American 294: 58 - 65.

Dria, K. J., J. R. Sachleben and P. G. Hatcher, 2002. Solid-state carbon-13 nuclear magnetic resonance of humic acids at high magnetic field strengths. Journal of Environmental Quality 31: $393-401$.

Duan, S. W., T. S. Bianchi and T. P. Sampere, 2007a. Temporal variability in the composition and abundance of terrestriallyderived dissolved organic matter in the lower Mississippi and Pearl Rivers. Marine Chemistry 103: $172-184$.

Duan, S. W., T. S. Bianchi, A. M. Shiller, K. Dria, P. G. Hatcher and K. R. Carman, 2007b. Variability in the bulk composition and abundance of dissolved organic matter in the lower Mississippi and Pearl rivers. Journal of Geophysical Research-Biogeosciences 112.

Emmenegger, L., R. R. Schönenberger, L. Sigg and B. Sulzberger, 2001. Light-induced redox cycling of iron in circumneutral lakes. Limnology and Oceanography 46: $49-61$.

Ertel, J. R., J. I. Hedges and E. M. Perdue, 1984. Lignin signature of aquatic humic substances. Science 223: $485-487$.

Ertel, J. R., J. I. Hedges, A. H. Devol, J. E. Richey and M. D. G. Ribeiro, 1986. Dissolved humic substances of the Amazon River system. Limnology and Oceanography 31: $739-754$.

Fan, T. W. M., R. M. Higashi and A. N. Lane, 2000. Chemical characterization of a chelator-treated soil humate by solutionstate multinuclear two-dimensional NMR with FTIR and pyrolysis-GCMS. Environmental Science and Technology 34: $1636-1646$

Faust, B. C. and R. G. Zepp, 1993. Photochemistry of aqueous iron(III) polycarboxylate complexes - Roles in the chemistry of atmospheric and surface waters. Environmental Science and Technology 27: 2517 - 2522 .

Fimmen, R. L., R. M. Cory, Y. P. Chin, T. D. Trouts and D. M. McKnight, 2007. Probing the oxidation-reduction properties of terrestrially and microbially derived dissolved organic matter. Geochimica Cosmochimica Acta 71: 3003 - 3015.

Frazier, S. W., L. A. Kaplan and P. G. Hatcher, 2005. Molecular characterization of biodegradable dissolved organic matter using bioreactors and $\left[{ }^{12} \mathrm{C} /{ }^{13} \mathrm{C}\right]$ tetramethylammonium hydroxide thermochemolysis GC-MS. Environmental Science and Technology 39: 1479 - 1491 .

Freeman, C., C. D. Evans, D. T. Monteith, B. Reynolds and N. Fenner, 2001. Export of organic carbon from peat soils. Nature 412: $785-785$.

Frimmel, F. H., 1998. Impact of light on the properties of aquatic natural organic matter. Environment International 24: 559 571.

Fulton, J. R., D. M. McKnight, C. M. Foreman, R. M. Cory, C. Stedmon and E. Blunt, 2004. Changes in fulvic acid redox state through the oxycline of a permanently ice-covered Antarctic lake. Aquatic Sciences 66: 27 - 46.

Gaberell, M., Y. P. Chin, S. J. Hug and B. Sulzberger, 2003. Role of dissolved organic matter composition on the photoreduction of $\mathrm{Cr}(\mathrm{VI})$ to $\mathrm{Cr}(\mathrm{III})$ in the presence of iron. Environmental Science and Technology 37: 4403-4409.

Gao, H. Z. and R. G. Zepp, 1998. Factors influencing photoreactions of dissolved organic matter in a coastal river of the southeastern United States. Environmental Science and Technology 32: 2940 - 2946.

Garrison, A. W., P. Schmitt and A. Kettrup, 1995. Capillary electrophoresis for the characterization of humic substances. Water Research 29: $2149-2159$.

Goldstone, J. V. and B. M. Voelker, 2000. Chemistry of superoxide radical in seawater: CDOM associated sink of superoxide in coastal waters. Environmental Science and Technology 34: $1043-1048$.

Goldstone, J. V., M. J. Pullin, S. Bertilsson and B. M. Voelker, 2002. Reactions of hydroxyl radical with humic substances: Bleaching, mineralization, and production of bioavailable carbon substrates. Environmental Science and Technology 36: 364 372.

Goni, M. A. and J. I. Hedges, 1992. Lignin dimers: Structures, 
distribution, and potential geochemical applications. Geochimica Cosmochimica Acta 56: 4025 - 4043

Granéli, W., M. Lindell and L. Tranvik, 1996. Photo-oxidative production of dissolved inorganic carbon in lakes of different humic content. Limnology and Oceanography 41: 698-706.

Granéli, W., M. Lindell, B. M. De Faria and F. D. Esteves, 1998. Photoproduction of dissolved inorganic carbon in temperate and tropical lakes - dependence on wavelength band and dissolved organic carbon concentration. Biogeochemistry 43: $175-195$.

Green, S. A. and N. V. Blough, 1994. Optical absorption and fluorescence properties of chromophoric dissolved organic matter in natural waters. Limnology and Oceanography 39: $1903-1916$.

Haag, W. R. and J. Hoigné, 1986. Singlet oxygen in surface waters. 3. Photochemical formation and steady-state concentrations in various types of waters. Environmental Science and Technology 20: $341-348$.

Hansell, D. A., D. Kadko and N. R. Bates, 2004. Degradation of terrigenous dissolved organic carbon in the western Arctic Ocean. Science 304: $858-861$.

Hassellöv, M., 2005. Relative molar mass distributions of chromophoric colloidal organic matter in coastal seawater determined by Flow Field-Flow Fractionation with UV absorbance and fluorescence detection. Marine Chemistry 94: $111-123$

Hatcher, P. G. and D. J. Clifford, 1994. Flash pyrolysis and in situ methylation of humic acids from soil. Organic Geochemistry 21: $1081-1092$.

Hatcher, P. G., K. J. Dria, S. Kim and S. W. Frazier, 2001. Modern analytical studies of humic substances. Soil Science 166: 770 794.

Hatcher, P. G., 2004. The CHNs of organic geochemistry: characterization of molecularly uncharacterized non-living organic matter. Marine Chemistry 92: $5-8$.

Hedges, J. I., W. A. Clark, P. D. Quay, J. E. Richey, A. H. Devol and U. D. Santos, 1986. Compositions and fluxes of particulate organic material in the Amazon River. Limnology and Oceanography 31: $717-738$.

Hedges, J. I., P. G. Hatcher, J. R. Ertel and K. J. Meyersschulte, 1992. A comparison of dissolved humic substances from seawater with Amazon River counterparts by ${ }^{13} \mathrm{C}-\mathrm{NMR}$ spectrometry. Geochimica Cosmochimica Acta 56: $1753-$ 1757.

Hedges, J. I., G. L. Cowie, J. E. Richey, P. D. Quay, R. Benner, M. Strom and B. R. Forsberg, 1994. Origins and processing of organic matter in the Amazon River as indicated by carbohydrates and amino acids. Limnology and Oceanography 39: $743-761$.

Hedges, J. I., R. G. Keil and R. Benner, 1997. What happens to terrestrial organic matter in the ocean? Organic Geochemistry 27: $195-212$

Hedges, J. I., E. Mayorga, E. Tsamakis, M. E. McClain, A. Aufdenkampe, P. Quay, J. E. Richey, R. Benner, S. Opsahl, B. Black, T. Pimentel, J. Quintanilla and L. Maurice, 2000. Organic matter in Bolivian tributaries of the Amazon River: A comparison to the lower mainstream. Limnology and Oceanography 45: $1449-1466$.

Hedges, J. I., J. A. Baldock, Y. Gelinas, C. Lee, M. L. Peterson and S. G. Wakeham, 2002. The biochemical and elemental compositions of marine plankton: A NMR perspective. Marine Chemistry 78: $47-63$.

Hefner, K. H., J. M. Fisher and J. L. Ferry, 2006. A multifactor exploration of the photobleaching of Suwannee River dissolved organic matter across the freshwater/saltwater interface. Environmental Science and Technology 40: 3717 - 3722

Helms, J. R., A. Stubbins, J. D. Ritchie, E. C. Minor, D. J. Kieber and K. Mopper, 2008. Absorption spectral slopes and slope ratios as indicators of molecular weight, source, and photobleaching of chromophoric dissolved organic matter. Limnology and Oceanography 53: 955 - 969 .

Hemminga, M. and C. M. Duarte, 2000. Seagrass Ecology, ed, Cambridg University Press, Cambridge.
Hernández, K. L., R. A. Quiñones, G. Daneri, M. E. Farias and E. W. Helbling, 2007. Solar UV radiation modulated daily production and DNA damage of marine bacterioplankton from a productive upwelling zone $\left(36^{\circ} \mathrm{S}\right)$, Chile. Journal of Experimental Marine Biology and Ecology 343: 82 - 95.

Herndl, G. J., G. Mullerniklas and J. Frick, 1993. Major role of ultraviolet-B in controlling bacterioplankton growth in the surface-layer of the ocean. Nature 361: 717 - 719 .

Herndl, G. J., A. Brugger, S. Hager, E. Kaiser, I. Obernosterer, B. Reitner and D. Slezak, 1997. Role of ultraviolet-B radiation on bacterioplankton and the availability of dissolved organic matter. Plant Ecology 128: 42 - 51 .

Hernes, P. J. and R. Benner, 2003. Photochemical and microbial degradation of dissolved lignin phenols: Implications for the fate of terrigenous dissolved organic matter in marine environments. Journal of Geophysical Research-Oceans 108.

Hernes, P. J. and R. Benner, 2006. Terrigenous organic matter sources and reactivity in the North Atlantic Ocean and a comparison to the Arctic and Pacific oceans. Marine Chemistry 100: $66-79$

Hertkorn, N., R. Benner, M. Frommberger, P. Schmitt-Kopplin, M. Witt, K. Kaiser, A. Kettrup and J. I. Hedges, 2006. Characterization of a major refractory component of marine dissolved organic matter. Geochimica Cosmochimica Acta 70: 2990 3010.

Hopkinson, C. S., I. Buffam, J. Hobbie, J. Vallino, M. Perdue, B. Eversmeyer, F. Prahl, J. Covert, R. Hodson, M. A. Moran, E. Smith, J. Baross, B. Crump, S. Findlay and K. Foreman, 1998. Terrestrial inputs of organic matter to coastal ecosystems: An intercomparison of chemical characteristics and bioavailability. Biogeochemistry 43: $211-234$.

Hu, F. S., J. I. Hedges, E. S. Gordon and L. B. Brubaker, 1999. Lignin biomarkers and pollen in postglacial sediments of an Alaskan lake. Geochimica Cosmochimica Acta 63: 1421 1430.

Jeffrey, W. H., P. Aas, M. M. Lyons, R. B. Coffin, R. J. Pledger and D. L. Mitchell, 1996. Ambient solar radiation-induced photodamage in marine bacterioplankton. Photochemistry and Photobiology 64: $419-427$.

Jiang, F. H., F. S. C. Lee, X. R. Wang and D. J. Dai, 2008. The application of Excitation/Emission Matrix spectroscopy combined with multivariate analysis for the characterization and source identification of dissolved organic matter in seawater of Bohai Sea, China. Marine Chemistry 110: 109 - 119.

Johannessen, S. C. and W. L. Miller, 2001. Quantum yield for the photochemical production of dissolved inorganic carbon in seawater. Marine Chemistry 76: $271-283$.

Jørgensen, N. O. G., L. Tranvik, H. Edling, W. Granéli and M. Lindell, 1998. Effects of sunlight on occurrence and bacterial turnover of specific carbon and nitrogen compounds in lake water. FEMS Microbiol. Ecol. 25: 217 - 227.

Judd, K. E., B. C. Crump and G. W. Kling, 2007. Bacterial responses in activity and community composition to photo-oxidation of dissolved organic matter from soil and surface waters. Aquatic Sciences 69: $96-107$.

Kaiser, E. and G. J. Herndl, 1997. Rapid recovery of marine bacterioplankton activity after inhibition by UV radiation in coastal waters. Applied and Environmental Microbiology 63: $4026-4031$

Kaiser, E., A. J. Simpson, K. J. Dria, B. Sulzberger and P. G. Hatcher, 2003. Solid-state and multidimensional solution-state NMR of solid phase extracted and ultrafiltered riverine dissolved organic matter. Environmental Science and Technology 37: 2929 - 2935.

Kaiser, E., D. B. Arscott, K. Tockner and B. Sulzberger, 2004. Sources and distribution of organic carbon and nitrogen in the Tagliamento River, Italy. Aquatic Sciences 66: $103-116$.

Kaiser, E. and B. Sulzberger, 2004. Phototransformation of riverine dissolved organic matter (DOM) in the presence of abundant iron: Effect on DOM bioavailability. Limnology and Oceanography 49: $540-554$.

Karlsson, J., M. Jansson and A. Jonsson, 2007. Respiration of 
allochthonous organic carbon in unproductive forest lakes determined by the Keeling plot method. Limnology and Oceanography 52: $603-608$.

Kawasaki, N. and R. Benner, 2006. Bacterial release of dissolved organic matter during cell growth and decline: Molecular origin and composition. Limnology and Oceanography 51: $2170-2180$.

Kelleher, B. P. and A. J. Simpson, 2006. Humic substances in soils: Are they really chemically distinct? Environmental Science and Technology 40: $4605-4611$.

Kieber, D. J., J. McDaniel and K. Mopper, 1989. Photochemical source of biological substrates in sea water: implications for carbon cycling. Nature 341: $637-639$.

Kieber, R. J., X. L. Zhou and K. Mopper, 1990. Formation of carbonyl compounds from UV-induced photodegradation of humic substances in natural waters: Fate of riverine carbon in the sea. Limnology and Oceanography 35: $1503-1515$.

Kim, S., L. A. Kaplan and P. G. Hatcher, 2006. Biodegradable dissolved organic matter in a temperate and a tropical stream determined from ultra-high resolution mass spectrometry. Limnology and Oceanography 51: $1054-1063$.

King, D. W., 1998. Role of carbonate speciation on the oxidation rate of $\mathrm{Fe}(\mathrm{II})$ in aquatic systems. Environmental Science and Technology 32: 2997 - 3003.

King, D. W. and R. Farlow, 2000. Role of carbonate speciation on the oxidation of $\mathrm{Fe}(\mathrm{II})$ by $\mathrm{H}_{2} \mathrm{O}_{2}$. Marine Chemistry 70: $201-$ 209.

Kortzinger, A., J. I. Hedges and P. D. Quay, 2001. Redfield ratios revisited: Removing the biasing effect of anthropogenic $\mathrm{CO}_{2}$. Limnology and Oceanography 46: 964 - 970.

Kowalczuk, P., W. J. Cooper, R. F. Whitehead, M. J. Durako and W. Sheldon, 2003. Characterization of CDOM in an organic-rich river and surrounding coastal ocean in the South Atlantic Bight. Aquatic Sciences 65: $384-401$.

Kowalczuk, P., J. Ston-Egiert, W. J. Cooper, R. F. Whitehead and M. J. Durako, 2005. Characterization of chromophoric dissolved organic matter (CDOM) in the Baltic Sea by excitation emission matrix fluorescence spectroscopy. Marine Chemistry 96: $273-292$.

Kowalczuk, P., C. A. Stedmon and S. Markager, 2006. Modeling absorption by CDOM in the Baltic Sea from season, salinity and chlorophyll. Marine Chemistry 101: $1-11$.

Kujawinski, E. B., R. Del Vecchio, N. V. Blough, G. C. Klein and A. G. Marshall, 2004. Probing molecular-level transformations of dissolved organic matter: insights on photochemical degradation and protozoan modification of DOM from electrospray ionization Fourier transform ion cyclotron resonance mass spectrometry. Marine Chemistry 92: 23 - 37.

Kulovaara, M., N. Corin, P. Backlund and J. Tervo, 1996. Impact of $\mathrm{UV}_{254}$-radiation on aquatic humic substances. Chemosphere 33: $783-790$.

Lam, B., A. Baer, M. Alaee, B. Lefebvre, A. Moser, A. Williams and A. J. Simpson, 2007. Major structural components in freshwater dissolved organic matter. Environmental Science and Technology 41: 8240 - 8247.

Langenheder, S., S. Sobek and L. J. Tranvik, 2006. Changes in bacterial community composition along a solar radiaion gradient in humic waters. Aquatic Sciences 68: $415-424$.

Larson, J. H., P. C. Frost, Z. Y. Zheng, C. A. Johnston, S. D. Bridgham, D. M. Lodge and G. A. Lamberti, 2007. Effects of upstream lakes on dissolved organic matter in streams. Limnology and Oceanography 52: 60 - 69.

Leu, E., S. Falk-Petersen and D. O. Hessen, 2007. Ultraviolet radiation negatively affects growth but not food quality of artic diatoms. Limnology and Oceanography 52: $787-797$.

Lindell, M. J., W. Granéli and L. J. Tranvik, 1995. Enhanced bacterial growth in response to photochemical transformation of dissolved organic matter. Limnology and Oceanography 40: $195-199$.

Louchouarn, P., S. Opsahl and R. Benner, 2000. Isolation and quantification of dissolved lignin from natural waters using solid-phase extraction and GC/MS. Analytical Chemistry 72: $2780-2787$.

Ma, X. and S. A. Green, 2004. Photochemical transformation of dissolved organic carbon in Lake Superior - An in-situ experiment. J. Great Lakes Res. 30 (Supplement): 97 - 112.

Mack, M. C., E. A. G. Schuur, M. S. Bret-Harte, G. R. Shaver and F. S. Chapin, 2004. Ecosystem carbon storage in arctic tundra reduced by long-term nutrient fertilization. Nature 431: 440 443.

Maie, N., C. Y. Yang, T. Miyoshi, K. Parish and R. F. Jaffe, 2005. Chemical characteristics of dissolved organic matter in an oligotrophic subtropical wetland/estuarine ecosystem. Limnology and Oceanography 50: 23 - 35 .

McCallister, S. L., J. E. Bauer and E. A. Canuel, 2006. Bioreactivity of estuarine dissolved organic matter: A combined geochemical and microbiological approach. Limnology and Oceanography 51: $94-100$.

McKnight, D. M., G. R. Aiken and R. L. Smith, 1991. Aquatic Fulvic-Acids in Microbially Based Ecosystems - Results from 2 Desert Lakes in Antarctica. Limnology and Oceanography 36: $998-1006$.

McKnight, D. M., E. W. Boyer, P. K. Westerhoff, P. T. Doran, T. Kulbe and D. T. Andersen, 2001. Spectrofluorometric characterization of dissolved organic matter for indication of precursor organic material and aromaticity. Limnology and Oceanography 46: $38-48$.

McKnight, D. M., E. Hood and L. Klapper, 2003. Trace organic moieties of dissolved organic material in natural waters. In: S. E. G. Findlay and R. L. Sinsabaugh (eds.), Aquatic Ecosystems: Interactivity of Dissolved Organic Matter, Academic Press, pp. $71-96$.

Meunier, L., H.-U. Laubscher, S. J. Hug and B. Sulzberger, 2005. Effects of size and origin of natural dissolved organic matter compounds on the redox cycling of iron in sunlit surface waters. Aquatic Sciences 67: 292 - 307.

Mikaloff Fletcher, S. E., N. Gruber, A. R. Jacobson, S. C. Doney, S. Dutkiewicz, M. Gerber, M. Follows, F. Joos, K. Lindsay, D. Menemenlis, A. Mouchet, S. A. Muller and J. L. Sarmiento, 2006. Inverse estimates of anthropogenic $\mathrm{CO}_{2}$ uptake, transport, and storage by the ocean. Global Biogeochemical Cycles 20: Art. No. GB2002.

Miller, W. L., D. W. King, J. Lin and D. R. Kester, 1995. Photochemical redox cycling of iron in coastal seawater. Marine Chemistry 50: $63-77$.

Miller, W. L. and R. G. Zepp, 1995. Photochemical production of dissolved inorganic carbon from terrestrial organic matter: Significance to the oceanic organic carbon cycle. Geophysical Research Letters 22: 417 - 420.

Minor, E. C., J. Pothen, B. J. Dalzell, H. Abdulla and K. Mopper, 2006. Effects of salinity changes on the photodegradation and ultraviolet-visible absorbance of terrestrial dissolved organic matter. Limnology and Oceanography 51: $2181-2186$.

Minor, E. C., B. J. Dalzell, A. Stubbins and K. Mopper, 2007. Evaluating the photoalteration of estuarine dissolved organic matter using direct temperature-resolved mass spectrometry and UV-visible spectroscopy. Aquatic Sciences 69.

Mladenov, N., D. M. McKnight, S. A. Macko, L. Ramberg, R. M. Cory and M. Norris, 2007. Chemical characterization of DOM in channels of a seasonal wetland. Aquatic Sciences 69.

Molot, L. A. and P. J. Dillon, 1997a. Colour mass balances and colour dissolved organic carbon relationships in lakes and streams in central Ontario. Canadian Journal of Fisheries and Aquatic Sciences 54: $2789-2795$.

Molot, L. A. and P. J. Dillon, 1997b. Photolytic regulation of dissolved organic carbon in northern lakes. Global Biogeochemical Cycles 11: 357 - 365 .

Molot, L. A., J. J. Hudson, P. J. Dillon and S. A. Miller, 2005. Effect of $\mathrm{pH}$ on photo-oxidation of dissolved organic carbon by hydroxyl radicals in a coloured, softwater stream. Aquatic Sciences 67: $189-195$.

Mopper, K., X. L. Zhou, R. J. Kieber, D. J. Kieber, R. J. Sikorski and R. D. Jones, 1991. Photochemical degradation of dissolved 
organic carbon and its impact on the oceanic carbon cycle Nature 353: $60-62$.

Mopper, K., A. Stubbins, J. D. Ritchie, H. M. Bialk and P. G. Hatcher, 2007. Advanced instrumental approaches for characterization of marine dissolved organic matter: Extraction techniques, mass spectrometry, and nuclear magnetic resonance spectroscopy. Chemical Reviews 107: 419 - 442.

Moran, M. A. and R. G. Zepp, 1997. Role of photoreactions in the formation of biologically labile compounds from dissolved organic matter. Limnology and Oceanography 42: $1307-1316$.

Moran, M. A., W. M. Sheldon and R. G. Zepp, 2000. Carbon loss and optical property changes during long-term photochemical and biological degradation of estuarine dissolved organic matter. Limnology and Oceanography 45: $1254-1264$.

Morel, A., B. Gentili, H. Claustre, M. Babin, A. Bricaud, J. Ras and F. Tieche, 2007. Optical properties of the "clearest" natural waters. Limnology and Oceanography 52: $217-229$.

Morris, D. P., H. Zagarese, C. E. Williamson, E. G. Balseiro, B. R. Hargreaves, B. Modenutti, R. Moeller and C. Queimalinos, 1995. The attentuation of solar UV radiation in lakes and the role of dissolved organic carbon. Limnology and Oceanography 40: $1381-1391$.

Morris, D. P. and B. R. Hargreaves, 1997. The role of photochemical degradation of dissolved organic carbon in regulating the UV transparency of three lakes on the Pocono Plateau. Limnology and Oceanography 42: $239-249$.

Murphy, K. R., C. A. Stedmon, T. D. Waite and G. M. Ruiz, 2008 Distinguishing between terrestrial and autochthonous organic matter sources in marine environments using fluorescence spectroscopy. Marine Chemistry 108: $40-58$.

Nieto-Cid, M., X. A. Alvarez-Salgado and F. F. Perez, 2006. Microbial and photochemical reactivity of fluorescent dissolved organic matter in a coastal upwelling system. Limnology and Oceanography 51: $1391-1400$.

Novotny, E. H., E. R. Deazevedo, T. J. Bonagamba, T. J. F. Cunha, B. E. Madari, V. D. Benites and M. H. B. Hayes, 2007. Studies of the compositions of humic acids from Amazonian Dark Earth soils. Environmental Science and Technology 41: 400 - 405.

Obernosterer, I., G. Kraay, E. De Ranitz and G. J. Herndl, 1999a. Concentrations of low molecular weight carboxylic acids and carbonyl compounds in the Aegean Sea (Eastern Mediterranean) and the turnover of pyruvate. Aquatic Microbial Ecology 20: 147 - 156.

Obernosterer, I., B. Reitner and G. J. Herndl, 1999b. Contrasting effects of solar radiation on dissolved organic matter and its bioavailability to marine bacterioplankton. Limnology and Oceanography 44: $1645-1654$.

Obernosterer, I. and R. Benner, 2004. Competition between biological and photochemical processes in the mineralization of dissolved organic carbon. Limnology and Oceanography 49: $117-124$.

Ogawa, H., Y. Amagai, I. Koike, K. Kaiser and R. Benner, 2001. Production of refractory dissolved organic matter by bacteria. Science 292: 917 - 920.

Opsahl, S. and R. Benner, 1997. Distribution and cycling of terrigenous dissolved organic matter in the ocean. Nature 386: $480-482$.

Opsahl, S. and R. Benner, 1998. Photochemical reactivity of dissolved lignin in river and ocean waters. Limnology and Oceanography 43: $1297-1304$.

Opsahl, S., R. Benner and R. M. W. Amon, 1999. Major flux of terrigenous dissolved organic matter through the Arctic Ocean. Limnology and Oceanography 44: $2017-2023$.

Pace, M. L. and J. J. Cole, 2002. Synchronous variation of dissolved organic carbon and color in lakes. Limnology and Oceanography 47: $333-342$.

Paul, A., R. Stosser, A. Zehl, E. Zwirnmann, R. D. Vogt and C. E. W. Steinberg, 2006. Nature and abundance of organic radicals in natural organic matter: Effect of $\mathrm{pH}$ and irradiation. Environmental Science and Technology 40: 5897 - 5903.

Perez, M. T. and R. Sommaruga, 2006. Differential effect of algaland soil-derived dissolved organic matter on alpine lake bacterial community composition and activity. Limnology and Oceanography 51: $2527-2537$.

Peterson, B. J., R. M. Holmes, J. W. McClelland, C. J. Vorosmarty, R. B. Lammers, A. I. Shiklomanov, I. A. Shiklomanov and S. Rahmstorf, 2002. Increasing river discharge to the Arctic Ocean. Science 298: $2171-2173$.

Powell, R. T. and A. Wilson-Finelli, 2003. Photochemical degradation of organic iron complexing ligands in seawater. Aquatic Sciences 65: $367-374$.

Pullin, M. J., S. Bertilsson, J. V. Goldstone and B. M. Voelker, 2004. Effects of sunlight and hydroxyl radical on dissolved organic matter: Bacterial growth efficiency and production of carboxylic acids and other substrates. Limnology and Oceanography 49: $2011-2022$.

Quan, T. M. and D. J. Repeta, 2007. Periodate oxidation of marine high molecular weight dissolved organic matter: Evidence for a major contribution from 6-deoxy- and methyl sugars. Marine Chemistry 105: 183 - 193.

Readfield, A. C., B. H. Ketchum and F. A. Richards, 1963. The influence of organisms on the composition of seawater. In: M. N. Hill (ed.), The Sea, Interscience, New York, pp. 26-77.

Reche, I., M. L. Pace and J. J. Cole, 1998. Interactions of photobleaching and inorganic nutrients in determining bacterial growth on colored dissolved organic carbon. Microbial Ecology 36: $270-280$.

Reche, I., M. L. Pace and J. J. Cole, 1999. Relationship of trophic and chemical conditions to photobleaching of dissolved organic matter in lake ecosystems. Biogeochemistry 44: 259 280.

Reche, I., M. L. Pace and J. J. Cole, 2000. Modeled effects of dissolved organic carbon and solar spectra on photobleaching in lake ecosystems. Ecosystems 3: $419-432$.

Reemtsma, T. and A. These, 2005. Comparative investigation of low-molecular-weight fulvic acids of different origin by SECQ-TOF-MS: New insights into structure and formation. Environmental Science and Technology 39: $3507-3512$.

Reemtsma, T., A. These, A. Springer and M. Linscheid, 2006. Fulvic acids as transition state of organic matter: Indications from high resolution mass spectrometry. Environmental Science and Technology 40: 5839 - 5845 .

Reemtsma, T., A. These, M. Linscheid, J. Leenheer and A. Spitzy, 2008. Molecular and structural characterization of dissolved organic matter from the deep ocean by FTICR-MS, including hydrophilic nitrogenous organic molecules. Environmental Science and Technology 42: 1430 - 1437.

Repeta, D. J. and L. I. Aluwihare, 2006. Radiocarbon analysis of neutral sugars in high-molecular-weight dissolved organic carbon: Implications for organic carbon cycling. Limnology and Oceanography 51: $1045-1053$.

Rodriguez-Roman, A., X. Hernandez-Pech, P. E. Thome, S. Enriquez and R. Iglesias-Prieto, 2006. Photosynthesis and light utilization in the Caribbean coral Montastraea faveolata recovering from a bleaching event. Limnology and Oceanography 51: $2702-2710$.

Rodriguez-Zuniga, U. F., D. Milori, W. T. L. Da Silva, L. MartinNeto, L. C. Oliveira and J. C. Rocha, 2008. Changes in optical properties caused by UV-irradiation of aquatic humic substances from the Amazon River basin: Seasonal variability evaluation. Environmental Science and Technology 42: 1948 1953.

Rush, J. D. and B. H. J. Bielski, 1985. Pulse radiolysis studies of the reactions of $\mathrm{HO}_{2} / \mathrm{O}_{2}^{-}$with ferric ions and its implication on the occurrence of the Haber-Weiss reaction. Journal of Physical Chemistry 89: $5062-5066$.

Schmitt-Kopplin, P., N. Hertkorn, H. R. Schulten and A. Kettrup, 1998a. Structural changes in a dissolved soil humic acid during photochemical degradation processes under $\mathrm{O}_{2}$ and $\mathrm{N}_{2}$ atmosphere. Environmental Science and Technology 32: $2531-$ 2541.

Schmitt-Kopplin, P., A. W. Garrison, E. M. Perdue, D. Freitag and A. Kettrup, 1998b. Capillary electrophoresis in the analysis of 
humic substances: Facts and artifacts. Journal Chromatography A 807: $101-109$.

Schmitt-Kopplin, P. and A. Kettrup, 2003. Capillary electrophoresis - electrospray spray ionization-mass spectrometry for the characterization of natural organic matter: An evaluation with free flow electrophoresis-off-line flow injection electrospray ionization-mass spectrometry. Electrophoresis 24: $3057-$ 3066.

Schmitt, D., M. B. Müller and F. H. Frimmel, 2001. Metal distribution in different size fractions of natural organic matter. Acta Hydrochimica et Hydrobiologica 28: 400 - 410 .

Schulten, H. R. and M. Schnitzer, 1997. Chemical model structures for soil organic matter and soils. Soil Science 162: 115 - 130.

Schwede-Thomas, S. B., Y.-P. Chin, K. J. Dria, P. G. Hatcher, E. Kaiser and B. Sulzberger, 2005. Characterizing the properties of dissolved organic matter isolated by XAD and C-18 solid phase extraction and ultrafiltration. Aquatic Sciences 67: 61 71.

Scully, N. M., W. J. Cooper and L. J. Tranvik, 2003. Photochemical effects on microbial activity in natural waters: the interaction of reactive oxygen species and dissolved organic matter. FEMS Microbiology Ecology 46: 353 - 357.

Scully, N. M., N. Maie, S. K. Dailey, J. N. Boyer, R. D. Jones and R. Jaffe, 2004. Early diagenesis of plant-derived dissolved organic matter along a wetland, mangrove, estuary ecotone. Limnology and Oceanography 49: $1667-1678$.

Seitzinger, S. P., H. Hartnett, R. Lauck, M. Mazurek, T. Minegishi, G. Spyres and R. Styles, 2005. Molecular-level chemical characterization and bioavailability of dissolved organic matter in stream water using electrospray-ionization mass spectrometry. Limnology and Oceanography 50: $1-12$.

Simjouw, J. P., E. C. Minor and K. Mopper, 2005. Isolation and characterization of estuarine dissolved organic matter: Comparison of ultrafiltration and $\mathrm{C}_{18}$ solid-phase extraction techniques. Marine Chemistry 96: $219-235$.

Simon, M. and B. Rosenstock, 2007. Different coupling of dissolved amino acid, protein, and carbohydrate turnover to heterotrophic picoplankton production in the Southern Ocean in austral summer and fall. Limnology and Oceanography 52: 85 - 95.

Simpson, A., 2001. Multidimensional solution state NMR of humic substances: A practical guide and review. Soil Science 166: $795-809$.

Simpson, A. J., G. X. Song, E. Smith, B. Lam, E. H. Novotny and M. H. B. Hayes, 2007. Unraveling the structural components of soil humin by use of solution-state nuclear magnetic resonance spectroscopy. Environmental Science and Technology 41: $876-883$.

Sleighter, R. L. and P. G. Hatcher, 2008. Molecular characterization of dissolved organic matter (DOM) along a river to ocean transect of the lower Chesapeake Bay by ultrahigh resolution electrospray ionization Fourier transform ion cyclotron resonance mass spectrometry. Marine Chemistry 110: $140-152$.

Smittenberg, R. H., T. I. Eglinton, S. Schouten and J. S. S. Damste, 2006. Ongoing buildup of refractory organic carbon in boreal soils during the Holocene. Science 314: 1283 - 1286.

Sobek, S., L. J. Tranvik, Y. T. Prairie, P. Kortelainen and J. J. Cole, 2007. Patterns and regulation of dissolved organic carbon: An analysis of 7,500 widely distributed lakes. Limnology and Oceanography 52: $1208-1219$.

Song, W. J., W. H. Ma, J. H. Ma, C. C. Chen and J. C. Zhao, 2005. Photochemical oscillation of $\mathrm{Fe}$ (II)/Fe(III) ratio induced by periodic flux of dissolved organic matter. Environmental Science and Technology 39: $3121-3127$.

Southworth, B. A. and B. M. Voelker, 2003. Hydroxyl radical production via the photo-Fenton reaction in the presence of fulvic acid. Environmental Science and Technology 37: 1130 1136.

Stabenau, E. R., R. G. Zepp, E. Bartels and R. G. Zika, 2004. Role of the seagrass Thalassia testudinum as a source of chromophoric dissolved organic matter in coastal south Florida. Marine Ecology-Progress Series 282: 59 - 72.

Stabenau, E. R. and R. G. Zika, 2004. Correlation of the absorption coefficient with a reduction in mean mass for dissolved organic matter in southwest Florida river plumes. Marine Chemistry 89: $55-67$.

Stedmon, C. A., S. Markager and H. Kaas, 2000. Optical properties and signatures of chromophoric dissolved organic matter $(\mathrm{CDOM})$ in Danish coastal waters. Estuarine Coastal and Shelf Science 51: $267-278$.

Stedmon, C. A. and S. Markager, 2005a. Tracing the production and degradation of autochthonous fractions of dissolved organic matter by fluorescence analysis. Limnology and Oceanography 50: $1415-1426$.

Stedmon, C. A. and S. Markager, 2005b. Resolving the variability in dissolved organic matter fluorescence in a temperate estuary and its catchment using PARAFAC analysis. Limnology and Oceanography 50: $686-697$.

Stubbins, A., V. Hubbard, G. Uher, C. S. Law, R. C. UpstillGoddard, G. R. Aiken and K. Mopper, 2008. Relating carbon monoxide photoproduction to dissolved organic matter functionality. Environmental Science and Technology 42: 3271 3276.

Sulzberger, B. and H. Laubscher, 1995. Reactivity of various types of iron(III) (hydr)oxides towards light-induced dissolution. Marine Chemistry 50: $103-115$.

Sutton, R. and G. Sposito, 2005. Molecular structure in soil humic substances: The new view. Environmental Science and Technology 39: 9009 - 9015.

Tranvik, L. J. and S. Bertilsson, 2001. Contrasting effects of solar UV radiation on dissolved organic sources for bacterial growth. Ecology Letters 4: 458 - 463 .

Tremblay, L. B., T. Dittmar, A. G. Marshall, W. J. Cooper and W. T. Cooper, 2007. Molecular characterization of dissolved organic matter in a North Brazilian mangrove porewater and mangrove-fringed estuaries by ultrahigh resolution Fourier Transform-Ion Cyclotron Resonance mass spectrometry and excitation/emission spectroscopy. Marine Chemistry 105: $15-29$.

Twardowski, M. S. and P. L. Donaghay, 2001. Separating in situ and terrigenous sources of absorption by dissolved materials in coastal waters. Journal of Geophysical Research-Oceans 106: $2545-2560$.

Twardowski, M. S. and P. L. Donaghay, 2002. Photobleaching of aquatic dissolved materials: Absorption removal, spectral alteration, and their interrelationship. Journal of Geophysical Research-Oceans 107: C8, 3091, DOI:3010.1029/ 1999JC000281.

Twardowski, M. S., E. Boss, J. M. Sullivan and P. L. Donaghay, 2004. Modeling the spectral shape of absorption by chromophoric dissolved organic matter. Marine Chemistry 89: $69-88$.

Vähätalo, A. V., K. Salonen, U. Munster, M. Jarvinen and R. G. Wetzel, 2003. Photochemical transformation of allochthonous organic matter provides bioavailable nutrients in a humic lake. Archiv für Hydrobiologie 156: 287 - 314.

Vähätalo, A. V. and R. G. Wetzel, 2004. Photochemical and microbial decomposition of chromophoric dissolved organic matter during long (months-years) exposures. Marine Chemistry 89: $313-326$.

Vähätalo, A. V. and R. G. Wetzel, 2008. Long-term photochemical and microbial decomposition of wetland-derived dissolved organic matter with alteration of C-13 : C-12 mass ratio. Limnology and Oceanography 53: $1387-1392$.

Valentine, R. L. and R. G. Zepp, 1993. Formation of carbon monoxide from the photodegradation of terrestrial dissolved organic carbon in natural waters. Environmental Science and Technology 27: $409-412$.

Vaughan, P. P. and N. V. Blough, 1998. Photochemical formation of hydroxyl radical by constituents of natural waters. Environmental Science and Technology 32: $2947-2953$.

Vodacek, A., F. E. Hoge, R. N. Swift, J. K. Yungel, E. T. Peltzer and N. V. Blough, 1995. The use of in situ and airborne fluorescence measurements to determine UV absorption coefficients and DOC concentrations in surface waters. Limnology and Oceanography 40: $411-415$.

Vodacek, A., N. V. Blough, M. D. Degrandpre, E. T. Peltzer and R. 
K. Nelson, 1997. Seasonal variation of CDOM and DOC in the Middle Atlantic Bight: Terrestrial inputs and photooxidation. Limnology and Oceanography 42: $674-686$.

Voelker, B. M., F. M. M. Morel and B. Sulzberger, 1997. Iron redox cycling in surface waters: Effects of humic substances and light. Environmental Science and Technology 31: $1004-1011$.

Voelker, B. M., D. L. Sedlak and O. C. Zafiriou, 2000. Chemistry of superoxide radical in seawater: Reactions with organic $\mathrm{Cu}$ complexes. Environmental Science and Technology 34: 1036 1042.

Vogt, R. D., J. Akkanen, D. O. Andersen, R. Bruggemann, B. Chatterjee, E. Gjessing, J. V. K. Kukkonen, H. E. Larsen, J. Luster, A. Paul, S. Pflugmacher, M. Starr, C. E. W. Steinberg, P. Schmitt-Kopplin and A. Zsolnay, 2004. Key site variables governing the functional characteristics of Dissolved Natural Organic Matter (DNOM) in Nordic forested catchments. Aquatic Sciences 66: $195-210$.

Waiser, M. J. and R. D. Robarts, 2000. Changes in composition and reactivity of allochthonous DOM in a prairie saline lake. Limnology and Oceanography 45: $763-774$.

Waite, T. D. and F. M. M. Morel, 1984. Photoreductive dissolution of colloidal iron oxide: Effect of citrate. Journal of Colloid and Interface Science 102: 121 - 137.

Wang, W., O. C. Zafiriou, I.-Y. Chan, R. G. Zepp and N. V. Blough, 2007b. Production of hydrated electrons from photoionization of dissolved organic matter in natural waters. Environmental Science and Technology 41: $1601-1607$.

Wang, X. C., L. Litz, R. F. Chen, W. Huang, P. Feng and M. A Altabet, 2007a. Release of dissolved organic matter during oxic and anoxic decomposition of salt marsh cordgrass. Marine Chemistry 105: 309 - 321.

Wangberg, S. A., K. I. M. Andreasson, K. Garde, K. Gustavson, P. Henriksen and T. Reinthaler, 2006. Inhibition of primary production by UV-B radiation in an arctic bay - model calculations. Aquatic Sciences 68: 117 - 128.

Warneck, P. and C. Wurzinger, 1988. Product quantum yields for the 305-nm photodecomposition of $\mathrm{NO}_{3}^{-}$in aqueous solution. Journal of Physical Chemistry 92: 6278 - 6283.

Weishaar, J. L., G. R. Aiken, B. A. Bergamaschi, M. S. Fram, R. Fujii and K. Mopper, 2003. Evaluation of specific ultraviolet absorbance as an indicator of the chemical composition and reactivity of dissolved organic carbon. Environmental Science and Technology 37: 4702 - 4708 .

Wells, M. L., L. M. Mayer, O. F. X. Donard, M. M. D. Sierra and S. G. Ackelson, 1991. The photolysis of colloidal iron in the oceans. Nature 353: $248-250$.

Wetzel, R. G., 1992. Gradient-dominated ecosystems: Sources and regulatory functions of dissolved organic matter in freshwater ecosystems. Hydrobiologia 229: 181 - 198.

Wetzel, R. G., P. G. Hatcher and T. S. Bianchi, 1995. Natural photolysis by ultraviolet irradiance of recalcitrant dissolved organic matter to simple substrates for rapid bacterial metabolism. Limnology and Oceanography 40: $1369-1380$.

White, E. M., P. P. Vaughan and R. G. Zepp, 2003. Role of the
photo-Fenton reaction in the production of hydroxyl radicals and photobleaching of colored dissolved organic matter in a coastal river of the southeastern United States. Aquatic Sciences 65: $402-414$.

Whitehead, K. and J. I. Hedges, 2003. Electrospray ionization tandem mass spectrometric and electron impact mass spectrometric characterization of mycosporine-like amino acids. Rapid Communications in Mass Spectrometry 17: 2133 - 2138.

Xie, H. X., O. C. Zafiriou, W. J. Cai, R. G. Zepp and Y. C. Wang, 2004. Photooxidation and its effects on the carboxyl content of dissolved organic matter in two coastal rivers in the Southeastern United States. Environmental Science and Technology 38: $4113-4119$.

Zafiriou, O. C., 1990. Chemistry of superoxide ion-radical $\left(\mathrm{O}_{2}^{-}\right)$in seawater. I. $p K_{\text {asw }}^{*}(\mathrm{HOO})$ and uncatalyzed dismuation kinetics studied by pulse radiolysis. Marine Chemistry 30: $31-43$.

Zanardi-Lamardo, E., C. A. Moore and R. G. Zika, 2004. Seasonal variation in molecular mass and optical properties of chromophoric dissolved organic material in coastal waters of southwest Florida. Marine Chemistry 89: 37 - 54.

Zang, X., J. D. H. Van Heemst, K. J. Dria and P. G. Hatcher, 2000. Encapsulation of protein in humic acid from a histosol as an explanation for the occurrence of organic nitrogen in soil and sediment. Organic Geochemistry 31: $679-695$.

Zepp, R. G. and P. F. Schlotzhauer, 1981. Comparison of the photochemical behavior of various humic substances in water. III. Spectroscopic properties of humic substances. Chemosphere 10: 479 - 486 .

Zepp, R. G., A. M. Braun, J. Hoigne and J. A. Leenheer, 1987. Photoproduction of hydrated electrons from natural organic solutes in aquatic environments. Environmental Science and Technology 21: $485-490$.

Zepp, R. G., W. M. Sheldon and M. A. Moran, 2004. Dissolved organic fluorophores in southeastern US coastal waters: correction method for eliminating Rayleigh and Raman scattering peaks in excitation-emission matrices. Marine Chemistry 89: $15-36$.

Zepp, R. G., D. J. Erickson, Iii, N. D. Paul and B. Sulzberger, 2007. Interactive effects of solar UV radiation and climate change on biogochemical cycling. Photochemical and Photobiological Sciences 6: $286-700$.

Zhang, Y., H. X. Xie and G. H. Chen, 2006. Factors affecting the efficiency of carbon monoxide photoproduction in the St. Lawrence estuarine system (Canada). Environmental Science and Technology 40: 7771 - 7777.

Ziolkowski, L. A. and W. L. Miller, 2007. Variability of the apparent quantum efficiency of $\mathrm{CO}$ photoproduction in the Gulf of Maine and Northwest Atlantic. Marine Chemistry 105: $258-270$.

Zuo, Y. G. and J. Holgné, 1992. Formation of hydrogen peroxide and depletion of oxalic acid in atmospheric water by photolysis of iron(III)-oxalato complexes. Environmental Science and Technology 26: $1014-1022$.

\section{To access this journal online: http://www.birkhauser.ch/AS}

